\title{
Review
}

\section{Aluminum Disruption of Calcium Homeostasis and Signal Transduction Resembles Change that Occurs in Aging and Alzheimer's Disease}

\author{
J.R. Walton* \\ UNSW Faculty of Medicine, University of New South Wales, St George Hospital Campus, Sydney, NSW, Australia
}

Accepted 7 December 2012

\begin{abstract}
Most humans living in industrialized societies are routinely exposed to bioavailable aluminum salts in the form of additives - in commercially-prepared foods, alum-clarified drinking water, certain pharmaceuticals, sunscreens, and other topical applications. Minute amounts of this aluminum are absorbed into the circulation. Trace aluminum levels cross the blood-brain barrier and progressively accumulate in large pyramidal neurons of the hippocampus, cortex, and other brain regions vulnerable in Alzheimer's disease. More aluminum enters the brain than leaves, resulting in a net increase in intraneuronal aluminum with advancing age. Aluminum is responsible for two main types of toxic damage in cells. As a pro-oxidant, aluminum causes oxidative damage both on its own and in synergy with iron. Aluminum also competes with, and substitutes for, essential metals-primarily $\mathrm{Mg}^{2+}$, iron and $\mathrm{Ca}^{2+}$ ions-in or on proteins and their co-factors. The author hypothesizes that intraneuronal aluminum interferes with $\mathrm{Ca}^{2+}$ metabolism in the aged brain and describes a way to test this hypothesis. This paper reviews: 1) major changes that occur in brain $\mathrm{Ca}^{2+}$ homeostasis and $\mathrm{Ca}^{2+}$ signaling, subtly with aging and more overtly in Alzheimer's disease; and 2) evidence from the scientific literature that aluminum causes these same changes in neurons.
\end{abstract}

Keywords: Aluminum, Alzheimer's disease, $\mathrm{Ca}^{2+}$-ATPase, calcium, calmodulin, G proteins, magnesium, neurotoxicant, oxidative damage, protein kinase $\mathrm{C}$, signal transduction

\section{INTRODUCTION}

Ionic calcium $\left(\mathrm{Ca}^{2+}\right)$, the physiologically active form of calcium, is a ubiquitous messenger that fulfils a central regulatory role in the metabolism of all cells. $\mathrm{Ca}^{2+}$ signals control a diverse set of biological processes in neurons, ranging from gene transcription, cell growth and differentiation to neurotransmission, synaptic plasticity, memory processing, and cell death. Healthy neurons have mechanisms that rigorously

*Correspondence to: Dr. J.R. Walton, Research and Education Centre, 4-10 South Street, Kogarah (Sydney), NSW 2217, Australia. Fax: +61 29113 3967; E-mail: j.walton@unsw.edu.au. control their intracellular $\mathrm{Ca}^{2+}$ content because prolonged elevation of the $\mathrm{Ca}^{2+}$ concentration would be excitotoxic [1-4]. For example, $\mathrm{Ca}^{2+}$ concentrations in neurons rise during neural activity from the resting level, peak, and then restore to the resting level, thus readying neurons for their next bout of activity. This requires normally functioning $\mathrm{Ca}^{2+}$ transport mechanisms, $\mathrm{Ca}^{2+}$ buffering proteins, and intracellular $\mathrm{Ca}^{2+}$ storage systems [5].

Subtle changes in $\mathrm{Ca}^{2+}$ homeostasis and signal transduction occur during aging that become more extensive and overt in Alzheimer's disease (AD) despite the elaborate biological controls in place to regulate $\mathrm{Ca}^{2+}$. A potential cause of these changes was 

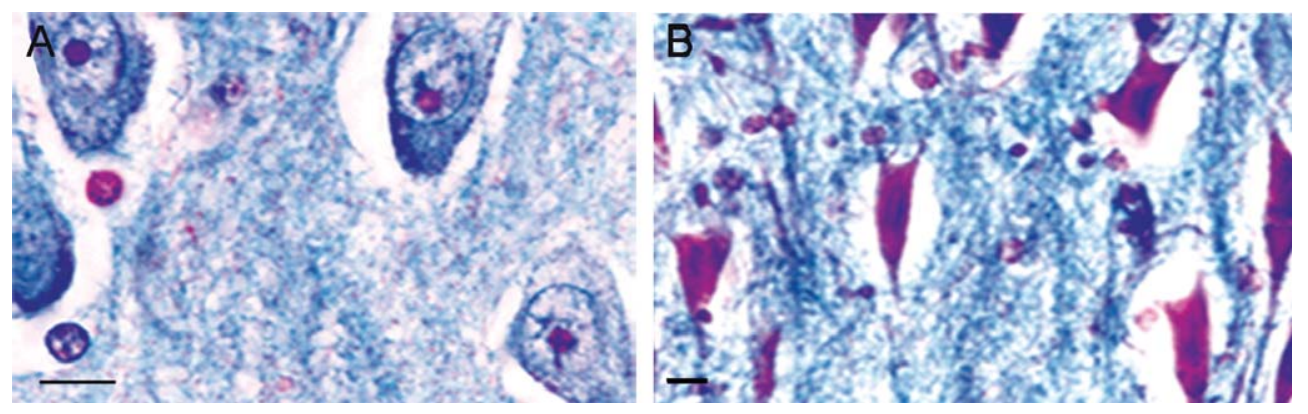

Fig. 1. Hippocampal pyramidal cells stained for Al from human brains of an age-matched non-demented control and a severely-affected AD case. A) Al stains the nucleoli magenta in aged controls denoting Stage I Al accumulation. B) These cells show stage V Al accumulation where Al staining occurs throughout the nucleus and cytoplasm of pyramidal cells. Reproduced from [109] with permission from Elsevier.

brought about by new 20th century industrial practices and products that now result in routine ingestion of aluminum (Al) throughout life from $\mathrm{Al}$ additives contained in commercially-prepared foods and alumtreated drinking water [6], and exposure to $\mathrm{Al}$ from other sources. Al salts have been increasingly used since the end of World War II as anti-caking agents in salt, coffee whiteners, pancake mixes and other powdered foods, emulsifiers and melting agents in cheeses, clarifying agents in water, puddings, and other processed foods where precipitates may form, as mordants for binding food dyes to solid foods, pickling agents, hardening agents for candying fruit, meat binders, gravy and sauce thickeners, rising agents in baking powders and baked goods, for buffering and as neutralizing agents. Other sources of $\mathrm{Al}$ exposure include topical applications, certain pharmaceuticals, some medical treatments, and Al-adjuvanted vaccines.

Trace amounts of $\mathrm{Al}$ are continuously taken up into the brain where $\mathrm{Al}$ shows net accumulation by old age [7-9]. Al particularly localizes in pyramidal neurons of brain regions specifically affected in AD [10-13] (Fig. 1A and B). In contrast to the essential nature of $\mathrm{Ca}^{2+}, \mathrm{Al}^{1}$ is an element that is non-essential for life and is toxic to living organisms. $\mathrm{Al}$ is abundant in the environment and evolution has provided mucus barriers for animal and plant protection. A mucus layer that lines the gastrointestinal tract, and another that coats the roots of plants, effectively exclude most (about 99.7\%) adventitious $\mathrm{Al}$ that these might encounter in the natural environment. However, the protective mucus barriers can be overwhelmed by human activity.

The author hypothesizes that intraneuronal Al interferes with $\mathrm{Ca}^{2+}$ metabolism in the aged human brain. An experiment is suggested to address this hypothesis.

\footnotetext{
1 The generic abbreviation "Al" is used throughout this report to collectively refer to all $\mathrm{Al}$ species present in solution.
}

The author endeavors to describe the status of changes in $\mathrm{Ca}^{2+}$ metabolism in association with $\mathrm{Al}$ as a significant element in the intraneuronal changes that occur in aging and in $\mathrm{AD}$, as will become evident from this review. Many of the reviewed studies will show that $\mathrm{Al}$ gives rise to cellular changes comparable to those associated with aging as it now occurs. These changes include: 1) elevation of the resting $\mathrm{Ca}^{2+}$ and peak $\mathrm{Ca}^{2+}$ levels in neuronal cytoplasm; 2) less $\mathrm{Ca}^{2+}$ influx; 3) a modest inhibition of phosphoinositide 4,5-biphosphate $\left(\mathrm{PIP}_{2}\right)$ hydrolysis by phosphoinositide-specific phospholipase C (PI-PLC) in phosphoinositide signaling pathways, resulting in less inositol triphosphate $\left(\mathrm{IP}_{3}\right)$ availability for signaling and protein kinase $\mathrm{C}$ (PKC) activation; and 4) a slower rate of $\mathrm{Ca}^{2+}$ removal from the cytoplasm. There are at least four major $\mathrm{Ca}^{2+}$ regulatory proteins that are fundamental to the main changes that occur in $\mathrm{Ca}^{2+}$ homeostasis and signaling, both in aging and AD.

The available evidence indicates the transition from aging to $\mathrm{AD}$, in relation to $\mathrm{Ca}^{2+}$ metabolism, is on a continuum with changes observed with aging that become disabling in $\mathrm{AD}$. $\mathrm{Al}$ inhibits the relevant proteins in a dose-dependent manner so it is possible that $\mathrm{AD}$ changes could result from the effects of progressive intraneuronal $\mathrm{Al}$ accumulation, on $\mathrm{Ca}^{2+}$ homeostasis and signal transduction, as increasing numbers of cells accumulate $\mathrm{Al}$ above the neurotoxic threshold. It is useful to first focus attention on the physical properties of $\mathrm{Al}$ that govern its interactions with essential cell metal ions, in order to better understand how $\mathrm{Al}$ can adversely affect $\mathrm{Ca}^{2+}$ metabolism.

\section{THE PHYSICAL PROPERTIES OF AL GOVERN ITS BEHAVIOR}

$\mathrm{Al}$ has complex chemistry. $\mathrm{Al}$ is a highly reactive element that forms various hydrolytic products with 
$\mathrm{pH}$-dependent solubilities in aqueous solutions. Ionic $\mathrm{Al}\left(\mathrm{Al}^{3+}\right)$, regarded as the most toxic of $\mathrm{Al}$ species, predominates below pH 5 [14] and equilibrates with other $\mathrm{Al}$ forms at higher $\mathrm{pH}$ values. Picomolar amounts of $\mathrm{Al}^{3+}$ produce toxic effects in biological processes at physiological $\mathrm{pH}$ [15].

The small size of the $\mathrm{Al}^{3+}$ ion, its near maximal charge : size ratio, and its lack of structure are its main properties [16]. Ionic size is more important than ionic charge for allowing substitution of a smaller metal ion in the catalytic site of a slightly larger metal ion [14]. The ionic radius of $\mathrm{Al}^{3+}$ is only $0.51 \AA$, partly as a result of the ion's strong electric charge. The $\mathrm{Al}^{3+}$ ion is almost as large as the ferric iron $\left(\mathrm{Fe}^{3+}\right)$ and somewhat smaller than the $\mathrm{Mg}^{2+}$ ion in their favored coordination state surrounded by six water molecules. $\mathrm{Al}$ is only about $1 / 9$ as large as the calcium ion $\left(\mathrm{Ca}^{2+}\right)$, making $\mathrm{Al}$ thermodynamically unlikely to substitute in a catalytic site normally occupied by $\mathrm{Ca}^{2+}$.

$\mathrm{Al}$ has high affinity, resulting from its very high charge density, that causes it to bind to almost any oxygen or nitrogen atom. Al has high affinity for $\mathrm{Mg}^{2+}$-binding sites in proteins. For example, $\mathrm{Al}$ affinity for the $\mathrm{Mg}^{2+}$-binding site in a $\mathrm{G}$ protein is approximately $10^{7}$ times higher than the affinity of $\mathrm{Mg}^{2+}$ [15]. Thus, nanomolar (nM) amounts of $\mathrm{Al}$ can successfully compete with the $\mathrm{mM}$ amounts of $\mathrm{Mg}^{2+}$ present within cells. A major problem with $\mathrm{Al}^{3+}$ competing with and substituting for essential metals in enzyme reactions is that these reactions normally rely on the metal having rapid reversible dissociation whereas $\mathrm{Al}$ has very slow release from the ligands to which it binds.

The order for metal exchange rate constants is shown in the list below [14], beginning with the slow exchange rate constant for $\mathrm{Al}$ and finishing with the fast exchange rate constant for $\mathrm{Ca}^{2+}$.

$$
\begin{aligned}
\mathrm{Al}^{3+} \ll \mathrm{Fe}^{3+}<\mathrm{Ga}^{3+}, \mathrm{Be}^{2+} \ll \mathrm{Mg}^{2+} \\
<\mathrm{Fe}^{2+}<\mathrm{Zn}^{2+}<\mathrm{Ca}^{2+}
\end{aligned}
$$

Each inequality sign represents a 10 -fold increase in the exchange rate, from $1.33 / \mathrm{sec}$ for $\mathrm{Al}^{3+}$ to $10^{8} / \mathrm{sec}$ for $\mathrm{Ca}^{3+}$ at $25^{\circ} \mathrm{C}$. Hence, $\mathrm{Al}^{3+}$ dissociates from biological ligands $10^{8}$ more slowly than $\mathrm{Ca}^{2+}$ and $10^{5}$ times more slowly than $\mathrm{Mg}^{2+}$. This slow exchange rate makes $\mathrm{Al}^{3+}$ a toxic substitute for essential metals in biological reactions where rapid dissociation is critical [14].

More than 300 proteins in cells are regulated by $\mathrm{Mg}^{2+}, \mathrm{ATP}-\mathrm{Mg}^{2+}$, or GTP-Mg${ }^{2+}$ co-factors $[17,18]$.
Almost all nucleoside phosphate reactions use $\mathrm{Mg}^{2+}$ so Al that accumulates in cells is an extremely effective surrogate for $\mathrm{Mg}^{2+}$, providing $\mathrm{Al}$ with many opportunities to disrupt critical enzyme reactions [14]. Some $\mathrm{Mg}^{2+}$-dependent proteins have important regulatory roles in $\mathrm{Ca}^{2+}$ homeostasis and $\mathrm{Ca}^{2+}$ signal transduction [19-22]. For example, activation of the calcium transporter protein, $\mathrm{Ca}^{2+}$-ATPase, requires $\mathrm{Mg}^{2+}$ binding to ATP to form the ATP- $\mathrm{Mg}^{2+}$ complex. $\mathrm{Al}^{3+}$ readily replaces $\mathrm{Mg}^{2+}$ in the ATP- $\mathrm{Mg}^{2+}$ complex to form an inactive ATP-Al ${ }^{3+}$ complex that renders the $\mathrm{Ca}^{2+}$-ATPase enzyme useless [14, 15, 23-25].

$\mathrm{Al}^{3+}$ also competes directly with $\mathrm{Ca}^{2+}$ for $\mathrm{Ca}^{2+}$ sites on membrane surfaces, on molecules in the cytoplasmic matrix, and in membrane $\mathrm{Ca}^{2+}$ channels. $\mathrm{Al}$ competes with both $\mathrm{Ca}^{2+}$ and $\mathrm{Mg}^{2+}$ for small ligand oxygen donors such as carboxyl and carbonyl groups, phosphate groups, inorganic phosphate, nucleotides and polynucleotides.

Moreover, the combination of high charge and small size causes $\mathrm{Al}^{3+}$ to have a strong polarizing effect on the electrons of adjacent oxygen atoms, particularly in phosphate groups. Al acts as a strong Lewis acid [26], pulling the polarized oxygen electrons toward itself. Al is a pro-oxidant, both on its own and in synergy with iron (e.g., [27, 28]).

Al produces biphasic effects in many of its biological reactions and these can occur either in time-dependent or dose-dependent manners. Biphasic effects are often apparent where $\mathrm{Al}^{3+}$ substitutes for $\mathrm{Mg}^{2+}$ in regulatory enzymes: initially stimulating enzyme activity and subsequently disrupting the same activity [29-31].

Likewise, trace amounts of $\mathrm{Al}^{3+}$ stimulate $\mathrm{G}$ protein-mediated transduction of receptor-generated signals in acute in vitro experiments [32] whereas larger than trace amounts of $\mathrm{Al}$ produce the opposite effect by inhibiting $\mathrm{G}$ protein-mediated signal transduction [33].

\section{CYTOPLASMIC CA ${ }^{2+}$ LEVEL INCREASE}

\section{Resting and peak cytoplasmic $\mathrm{Ca}^{2+}$ levels increase in aged neural cells}

Many research groups have reported that $\mathrm{Ca}^{2+}$ levels, in hippocampal and cortical neurons of older rats, rabbits, and monkeys, peak at higher levels during neural activity and are maintained at higher levels under resting conditions than in the same neurons of young animals (e.g., [34-43]). $\mathrm{Ca}^{2+}$ levels are probably also higher in aged human neurons but evidence for 
this is obscured by postmortem-change [44]. According to Green and LaFerla [45], increased levels of $\mathrm{Ca}^{2+}$-dependent proteases such as calpain provide circumstantial evidence of $\mathrm{Ca}^{2+}$ disruption in $\mathrm{AD}$ in lieu of direct evidence.

\section{Al increases the cytoplasmic $\mathrm{Ca}^{2+}$ level in neural cells}

An alternate explanation for increased levels of the $\mathrm{Ca}^{2+}$-dependent proteases calpain and apopain in $\mathrm{AD}$ brain tissue is that these result from $\mathrm{Al}$ accumulation because $\mathrm{AD}$-affected brain tissue has a 2 to 3 -fold increase in $\mathrm{Al}$ content over that of non-demented controls [46] and in vivo Al exposure increases the levels of calpain and apopain in brain tissue relative to untreated controls [47].

Experimental treatments with either oral Al, intraperitoneally-injected $\mathrm{Al}$ or tail-vein injection concurrently raise $\mathrm{Al}$ and $\mathrm{Ca}^{2+}$ in brain tissue of rabbits, rats, mice, and monkeys [48-53]. $\mathrm{Ca}^{2+}$ levels are twice as high in brains of Al-treated animals as in brains of unexposed controls [48, 51]. Most $\mathrm{Ca}^{2+}$ increase occurs in the cortex, followed by the hippocampus and then the striatum.

Direct injection of $\mathrm{Al}$ lactate into the brain ventricles of young rabbits has been used to raise brain Al levels sufficiently high to produce an acute animal model for $\mathrm{Al}$ encephalopathy in renal failure patients [54]. The rabbit forebrain exhibits progressive increase in $\mathrm{Ca}^{2+}$ content as the encephalopathy evolves, from a control value of $263 \mu \mathrm{g} \mathrm{Ca}^{2+} / \mathrm{g}$ brain tissue (dry weight) to $294 \mu \mathrm{g} / \mathrm{g}$ by 12 days, $340 \mu \mathrm{g} / \mathrm{g}$ by 20 days, and $550 \mu \mathrm{g} / \mathrm{g}$ post-injection by 29 days as the rabbits became symptomatic, exhibiting seizures and entering the terminal stage of encephalopathy [54]. The controls, injected only with sodium lactate in water, are spared these effects.

This effect can also be seen in cultured neural cells. Glutamate stimulation causes ${ }^{45} \mathrm{Ca}^{2+}$ levels in cultured neurons to rise and peak at up to $280 \%$ of the normal resting ${ }^{45} \mathrm{Ca}^{2+}$ level. If cells are exposed to $\mathrm{Al}$ prior to glutamate stimulation, their ${ }^{45} \mathrm{Ca}^{2+}$ level peaks around $400 \%$ of the ${ }^{45} \mathrm{Ca}^{2+}$ resting level and plateaus at a higher level than in cells exposed to glutamate without $\mathrm{Al}$ pre-exposure [55]. Also, astrocytes cultured in the presence of 100,200 , or $400 \mu \mathrm{M} \mathrm{Al}^{3+}$ for 1 day show a significant $(>50 \%)$ dose-dependent increase in their basal $\mathrm{Ca}^{2+}$ level compared with that of unexposed controls. Their basal $\mathrm{Ca}^{2+}$ level further increases in a time-dependent manner by $130 \%$ when $\mathrm{Al}^{3+}$ exposure is lengthened to 6 days [56].
The in vivo $\mathrm{Al}$ accumulation that progressively occurs in human neurons and astrocytes throughout life $[6,13]$ provides a reasonable explanation for the elevations observed in resting and peak cytoplasmic $\mathrm{Ca}^{2+}$ levels of aged individuals [47, 51, 53, 57]. Also, Garruto et al. [58] have observed that high brain levels of $\mathrm{Ca}^{2+}$ parallel high $\mathrm{Al}$ levels in most human neurodegenerative conditions linked to Al neurotoxicity.

\section{$\mathrm{CA}^{2+}$ INFLUX INTO NEURONS}

Less $\mathrm{Ca}^{2+}$ flows through plasma membrane $\mathrm{Ca}^{2+}$ channels of aged and AD-affected neural cells

Most $\mathrm{Ca}^{2+}$ influx is through N-methyl-D-aspartate (NMDA) receptors [59]. Hippocampal CA1 cells from old rats exhibit significantly (30-40\%) less NMDA receptor binding, suggesting that aged neurons either have fewer NMDA receptors per cell surface area or less efficient binding to their NMDA receptors [60, 61]. Similarly, in $\mathrm{AD}, \mathrm{Ca}^{2+}$ influx through NMDA receptors is lowered, either because the NMDA receptors are unable to bind glutamate or as a result of lower NMDA receptor density in AD hippocampal tissue [62-64].

Voltage-gated calcium channels (VGCCs) play a pivotal role in coupling electrical activity to neurotransmission. Aged neurons have a higher density of VGCCs in their plasma membrane than young neurons [65]. However, patch clamp experiments have demonstrated that many VGCCs in old neurons are non-functional indicating that L-type VGCC activity is relatively low in old CA1 hippocampal neurons regardless of their VGCC density [66]. Moreover, the fast phase of $\mathrm{Ca}^{2+}$ uptake is diminished in synaptosomes prepared from rats at age 24 months compared to those from rats at age 3 months [67]. Thus, older neurons have reduced $\mathrm{Ca}^{2+}$ influx and are less excitable than their younger counterparts [68-71]. In view of these findings, the mechanism for $\mathrm{Ca}^{2+}$ elevation in aged neurons, during activity and at rest, must involve some process other than increased $\mathrm{Ca}^{2+}$ influx.

\section{Al decreases $\mathrm{Ca}^{2+}$ influx into neural cells}

Al decreases glutamate-activated NMDA and $\alpha-$ amino-3-hydroxy-5-methylisoxazle-4-proprionic acid (AMPA) $\mathrm{Ca}^{2+}$ currents by $50 \%$ [72, 73]. Furthermore, Al reduces expression of the NMDA receptor $\alpha$ gene in a dose-dependent manner $(p<0.01)$ [74].

NMDA $\mathrm{Ca}^{2+}$ influx is also inhibited in hippocampal neurons by exposing them to okadaic acid, an inhibitor of the serine/threonine (Ser/Thr) protein phosphatases 
PP1 and 2A (PP2A) [75]. This is relevant to this review because $\mathrm{Al}$ is also a Ser/Thr protein phosphatase (PP) inhibitor: for PP1 [76], PP2A [77, 78], and PP2B [79]. The Al accumulation that occurs in rat hippocampal and cortical neurons, after chronic consumption of $\mathrm{Al}$ at human-equivalent $\mathrm{Al}$ exposure levels (adjusted for mg. $\mathrm{kg}^{-1}$ body weight (bw)), is sufficient to inhibit PP2A activity in vivo [78]. Hence, $\mathrm{Al}$ inhibition of Ser/Thr phosphatase activity may be one more factor that impedes $\mathrm{Ca}^{2+}$ influx through NMDA receptors.

$\mathrm{Al}$ decreases the fast phase of $\mathrm{Ca}^{2+}$ uptake through VGCCs in vitro and in vivo [51, 80]. Fast phase $\mathrm{Ca}^{2+}$ channels are those principally involved in neurotransmitter release [80]. Al retardation of $\mathrm{Ca}^{2+}$ influx occurs from competitive and non-competitive interactions between $\mathrm{Al}$ and $\mathrm{Ca}^{2+}$, as $\mathrm{Al}$ prevents $\mathrm{Ca}^{2+}$ from reaching $\mathrm{Ca}^{2+}$ binding sites on and within VGCCs [47, 52, 80, 81]. Furthermore, the low ${ }^{45} \mathrm{Ca}^{2+}$ influx that occurs in the presence of $\mathrm{Al}$ has a depressant effect on PKC activity and PKC-regulated physiological processes [82].

Al blocks $\mathrm{Ca}^{2+}$ influx into cultured neurons in a manner that involves both transient and sustained components for all main types of VGCCs. This blockage is strongly pH-dependent and is irreversible [81, 83]. Direct application of $\mathrm{Al}^{3+}$ to the external or internal face of the plasma membrane of these cells inhibits $\mathrm{Ca}^{2+}$ influx through VGCCs in a concentration- dependent manner with an $\mathrm{IC}_{50}$ at $2.3 \mu \mathrm{g} / \mathrm{ml}$ or $83 \mu \mathrm{M}$ Al [81, 83].

${ }^{45} \mathrm{Ca}^{2+}$ influx fails to occur through VGCCs of synaptosomes prepared from the hippocampus and cortex of monkeys and rats chronically exposed to oral $\mathrm{Al}$, even when placed in a high potassium solution that depolarizes their membrane [48, 52, 80]. An investigation of $\mathrm{Al}$ influence on high voltage-dependent calcium current $\left(\mathrm{I}_{\mathrm{HVA}}\right)$, using a patch-clamp technique with hippocampal CA1 neurons isolated from weanling rats, revealed that $\mathrm{Al}$ produces biphasic effects on the IHVA, with $\mathrm{Al}$ concentrations lower than $250 \mu \mathrm{M}$ decreasing the $\mathrm{I}_{\mathrm{HVA}}$ [31]. Al levels in aged human hippocampal and cortical neurons are generally in the $10-250 \mu \mathrm{M}$ range [84], making this $\mathrm{Ca}^{2+}$ current susceptible to $\mathrm{Al}$ inhibition.

Amyloid- $\beta$ forms calcium channels in bilayer membranes of PC-12 cells [85] and of liposomes [86]. $\mathrm{Ca}^{2+}$ influx through amyloid- $\beta$ channels that form in liposomes is irreversibly blocked by 10 to $20 \mu \mathrm{M} \mathrm{Al}$ [86].

\section{$\mathrm{CA}^{2+}$ /PHOSPHOINOSITIDE SIGNALING PATHWAYS}

The events that occur in a typical phosphoinositide signaling pathway are shown diagrammatically in Fig. 2A. After an agonist (for example, acetylcholine) stimulates its receptor, the receptor normally couples

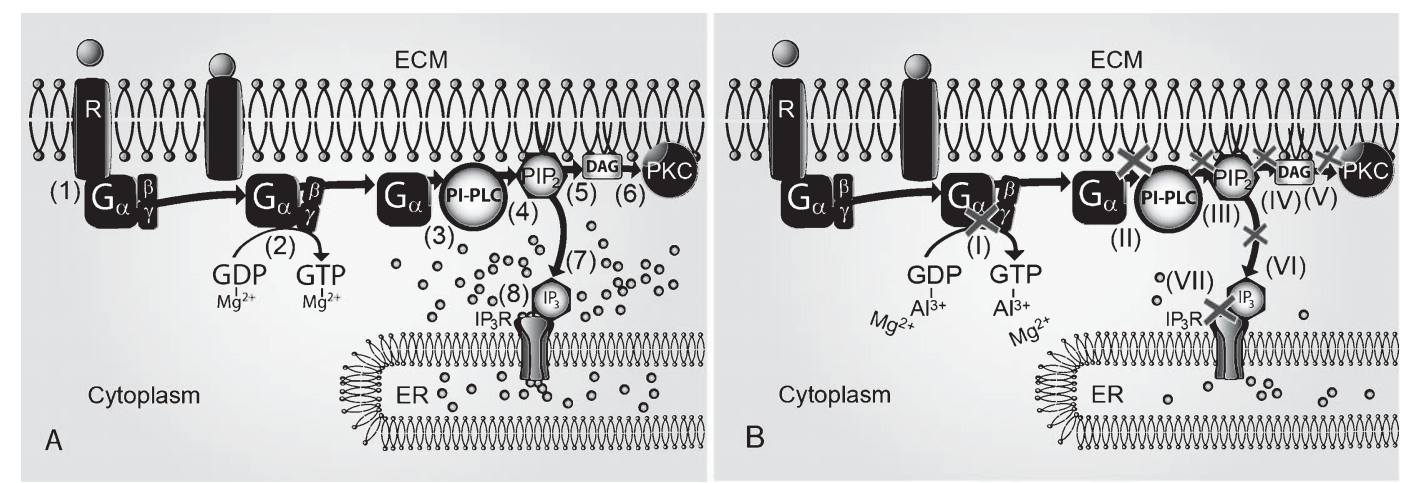

Fig. 2. A phosphoinositide signaling pathway, in health, Alzheimer's disease, and Al neurotoxicity. A) In healthy neural cells, a tripartite G protein (1) is coupled to an inactive plasma membrane receptor (R) as a (spherical) agonist approaches. The agonist attaches to the end of the receptor facing the extracellular matrix and initiates a cascade of intracellular events. The G $\alpha$ subunit of the G protein becomes activated by GDP/GTP exchange (2), and dissociates from the receptor, and from its $\beta$ and $\gamma$ constituents. The G $\alpha$ subunit activates PI-PLC (3) which hydrolyzes $\mathrm{PIP}_{2}$ (4), giving rise to the second messengers $\mathrm{IP}_{3}(7)$ and DAG (5). The $\mathrm{IP}_{3}$ diffuses to $\mathrm{IP}_{3} \mathrm{R}$ in the ER membrane, stimulating Ca ${ }^{2+}$ release (8) for signaling from ER stores. DAG activates PKC (6), which translocates to the plasma membrane. B) The phosphoinositide signaling pathway is damaged at virtually the same loci in Al-exposed neurons as in AD. Experimental evidence indicates that G protein activation, which normally occurs by GTP-GDP exchange (I), is blocked by $\mathrm{Al}^{3+}$ substitution for $\mathrm{Mg}^{2+}$ in GDP and GTP. Consequently, the G $\alpha$ subunit fails to activate PI-PLC (II) which in turn impairs its ability to hydrolyze PIP $_{2}$ (III) and the formation of DAG (IV) and IP 3 (VI). DAG thus fails to activate PKC (V) and insufficient $\mathrm{IP}_{3}$ is available to stimulate its receptor to release $\mathrm{Ca}^{2+}$ from the ER (VII) into the cytoplasm for Ca ${ }^{2+}$ signaling. 
to and activates $\mathrm{G}$ protein. The activated $\mathrm{G}$ protein in turn activates PI-PLC which requires $\mathrm{Ca}^{2+}$ to cleave $\mathrm{PIP}_{2}$. Cleavage of $\mathrm{PIP}_{2}$ results in the formation of diacylglycerol (DAG) and $\mathrm{IP}_{3}$. $\mathrm{IP}_{3}$ diffuses to its receptors in the endoplasmic reticulum (ER), thereby stimulating them to release $\mathrm{Ca}^{2+}$, and DAG activates PKC. A more simple pathway consists of direct $\mathrm{Ca}^{2+}$ stimulation of PI-PLC, bypassing G protein activation. Noradrenalin apparently utilizes both agonist- and $\mathrm{Ca}^{2+}$-stimulated pathways for phosphoinositide hydrolysis [87].

\section{$\mathrm{Ca}^{2+} /$ phosphoinositide signaling pathways are perturbed with aging and are more disrupted in AD-affected neural cells}

At least eight of ten studies have shown significant age-related decrements in agonist-stimulated phosphoinositide signaling pathways in older neural cells [88-97]. Phosphoinositide signaling pathways are even more disrupted in neural cells affected by AD [98-101]. Al interference is apparent at several locations within these pathways, as described below.

\section{$G$ protein activation is severely inhibited in} AD-affected neural cells

AD brain cytopathology exhibits general dysfunction in $G$ proteins, and in their activation by guanosine dinucleotide (GDP)/guanosine trinucleotide (GTP) exchange [review, 102]. G protein activation has crucial importance in phosphoinositide pathways because guanine nucleotide binding is regarded as the rate-limiting step for $\mathrm{G}$ protein-mediated signal amplification from receptor to effector [24].

\section{Al inhibits $G$ protein activation in neural cells}

$\mathrm{Al}^{3+}$ substitution for $\mathrm{Mg}^{2+}$ in GDP and GTP prevents the exchange of GTP for the GDP bound to the G protein and thereby causes a profound impairment of $\mathrm{G}$ protein activation [23, 33] (Fig. 2B). Several examples illustrate ways that $\mathrm{Al}$ inhibits $\mathrm{G}$ protein function in dose-dependent manner [103-107]. A detailed investigation of the effects of $\mathrm{Al}^{3+}$ on bovine retinal $\mathrm{G}_{\mathrm{v}}$ protein (transducin), as a general model for $G$ protein activity, used nitrilotriacetic acid to precisely control the free $\mathrm{Al}^{3+}$ level. This showed that $4 \mathrm{pM} \mathrm{Al}^{3+}$ is sufficient to substitute for $\mathrm{Mg}^{2+}$, an essential co-factor for $\mathrm{G}$ protein activation, and to inhibit receptor-mediated $G$ protein activation [24].

Tubulin is a $\mathrm{G}$ protein [108]. G $\alpha$ subunits of specific G proteins associated with tubulin are activated by GTP transfer from tubulin's exchangeable GTP-binding site to the $\mathrm{G} \alpha$ subunit. $\mathrm{Al}^{3+}$ initially stimulates in vitro assembly of tubulin sub-units into microtubules. This was determined by assessing the association constants for $\mathrm{Al}^{3+}, \mathrm{Mg}^{2+}$, and the GTP/tubulin ternary complex required for polymerization. $\mathrm{Al}^{3+}$ competes with $\mathrm{Mg}^{2+}$, the physiological mediator of microtubule assembly [15], and has an association constant for the GTP/tubulin ternary complex that is $10^{7}$ times stronger than that of $\mathrm{Mg}^{2+}$. Tubulin subunits acutely exposed to $\mathrm{Al}$ in minute amounts show that $\mathrm{Al}$ levels as low as $4 \times 10^{-10} \mathrm{M}$ compete effectively with $\mathrm{mM}$ amounts of $\mathrm{Mg}^{2+}$ for tubulin polymerization. The Al-catalyzed microtubules appear ultrastructurally identical to normal microtubules but are functionally defective. Al-catalyzed microtubules are incapable of responding to $\mathrm{Ca}^{2+}$-regulated depolymerisation and their rate of GTP hydrolysis is markedly lower than normal [15]. Aged rats that consumed dietary Al at human-relevant levels throughout their middle age and old age, accumulate varying amounts of stainable $\mathrm{Al}$ in their neurons. When neurons with high stage $\mathrm{Al}$ accumulation were immunostained with an antibody against acetylated tubulin, those neurons failed to show microtubules whereas microtubules were clearly visible in adjacent cells that exhibit smaller amounts of stainable Al [109].

\section{Phosphoinositide hydrolysis by phosphoinositide-specific phospholipase $C$ (PI-PLC)}

Phosphoinositide hydrolysis by PI-PLC is impaired in AD-affected neural cells

Activated $G$ protein is normally able to amplify the signal from the receptor that causes the effector protein PI-PLC to hydrolyze $\mathrm{PIP}_{2}$ and form DAG and $\mathrm{IP}_{3}$. PI-PLC also cleaves phosphotidylinositol to form other phosphoinositides, leading to their accumulation in the membrane. Basal PI-PLC hydrolysis appears to be the same for brains from AD cases and controls $[98,102]$ but studies of carbachol/GTP $\gamma[S]-$ stimulated, serotonin/GTP $\gamma[\mathrm{S}]$-stimulated, and GTP $\gamma$ [S]-stimulated phosphoinositide hydrolysis by PI-PLC in membranes prepared from $\mathrm{AD}$ and control postmortem prefrontal cortex, and from several other brain regions, show $40 \%-50 \%$ deficits in PI-PLC activity of AD brain tissue compared to aged controls [110].

\section{Al inhibits phosphoinositide hydrolysis by PI-PLC in neural cells}

Acute inhibitory effects of $\mathrm{Al}$ on phosphoinositide accumulation and $\mathrm{PIP}_{2}$ hydrolysis by PI-PLC have been confirmed in a variety of experimental systems: 
in synaptosomes [111], cortical homogenates [111], hippocampal and cortical slices [103, 111-113], neuroblastoma cells [33, 56, 114], and liposomes [115, 116]. Aluminum lactate and aluminum chloride have similar efficacy for inhibiting phosphoinositide accumulation in rat cortical slices [107]. The inhibitory effect of $\mathrm{Al}^{3+}$ on $\mathrm{PIP}_{2}$ hydrolysis by phospholipase $\mathrm{C}$ is conserved and consistent, occurring even in plant cells [117].

Al depresses phosphoinositide hydrolysis by PIPLC in both agonist- and non-agonist-stimulated phosphoinositide pathways $[33,56,104,107$, 111-114]. For example, 10-500 $\mu \mathrm{M}$ Al inhibits $\mathrm{PIP}_{2}$ hydrolysis by PI-PLC in cortical homogenates in a dose-dependent manner with an $\mathrm{IC}_{50}$ of $100 \mu \mathrm{M}$ [107].

McDonald and Mamrack [29] analyzed PI-PLC activity in a defined system using purified PI-PLC and showed that $\mathrm{Al}^{3+}$ inhibits the hydrolysis of $5 \mu \mathrm{M}$ $\mathrm{PIP}_{2}$ by PI-PLC in a dose-dependent manner with a $50 \%$ inhibitory concentration $\left(\mathrm{IC}_{50}\right)$ of approximately $0.2 \mu \mathrm{M} \mathrm{AlCl}$, with $\mathrm{AlCl}_{3}$ concentrations ranging from $1 \mathrm{nM}$ to $10 \mathrm{mM}$ (Fig. 3). McDonald and Mamrack observed that $\mathrm{Al}$ affects the hydrolysis of phosphatidylinositols in a biphasic manner. Al concentrations below $8 \mu \mathrm{M}$ are without effect. From 8-10 $\mu \mathrm{M}$ Al produces an increase, enhancing the continued hydrolytic breakdown of phosphoinositides by PI-PLC and leading to their accumulation in the

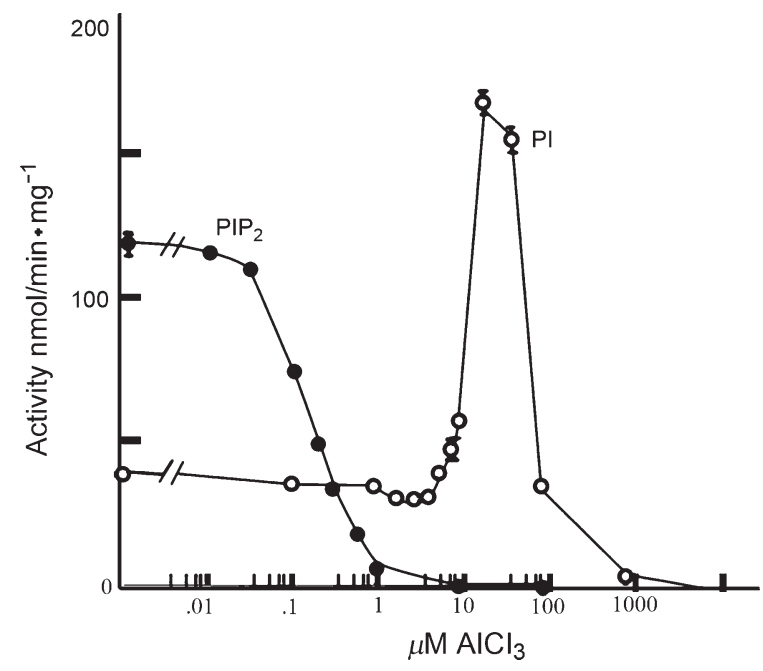

Fig. 3. Phosphoinositide and $\mathrm{PIP}_{2}$ hydrolysis in the presence of aluminum chloride. Increasing concentrations of $\mathrm{AlCl}_{3}$ produce a biphasic effect on phosphoinositide (PI) hydrolysis (open circles). PI hydrolysis is stimulated at $10 \mu \mathrm{M} \mathrm{Al}$ and inhibited at concentrations above $25 \mu \mathrm{M}$. In contrast, $\mathrm{PIP}_{2}$ hydrolysis (closed circles) is inhibited at $0.01 \mu \mathrm{M} \mathrm{Al}$ or higher. Redrawn from [28] with permission from Elsevier. reaction mixture. Al concentrations above $10 \mu \mathrm{M}$ decrease the hydrolytic activity of PI-PLC on phosphoinositides [29].

Al decreases phosphatidylinositol accumulation in neonatal rats as well as adult rats [113]. Phosphatidylinositol accumulation in rat cortical and hippocampal slices is significantly inhibited by $10-100 \mu \mathrm{M} \mathrm{Al}$ in the presence of agonists for muscarinic, adrenergic or metabotropic receptors $[111,112]$. In the absence of agonists, ten times more $\mathrm{Al}$ is required to inhibit phosphatidylinositol accumulation in brain slices and in synaptosomes.

Some evidence suggests that $\mathrm{Al}$ directly inhibits PI-PLC activity [57, 104, 111, 113, 114]. Other evidence suggests Al indirectly inhibits PI-PLC activity by altering $\mathrm{PIP}_{2}$ availability $[29,106,107]$. Al inhibition of PI-PLC activity is probably non-competitive with $\mathrm{Ca}^{2+}$ as the $\mathrm{Ca}^{2+}$ concentration curve is unaltered [107, 112] whereas interaction between $\mathrm{Al}$ and $\mathrm{PIP}_{2}$ is competitive [107]. A third possible mechanism involves the disruptive influence that Al has on calmodulin $(\mathrm{CaM})$ which is a modulator of PI-PLC activity [118].

\section{Inhibition of phosphoinositide signaling pathways reduce $P K C$ activation}

\section{Decrements in phosphoinositide signaling} pathways of aged and AD neural cells results in less protein kinase $C$ activation by diacylglycerol

PKC is normally activated by DAG, generated from $\mathrm{PIP}_{2}$ hydrolysis, which shifts soluble PKC to a particulate or membrane-bound form [119]. PKC activity is more erratic in the neocortex and hippocampus of aged rats, decreasing in older cortex by $45 \%$ of the value found in young controls while increasing in the aged hippocampus [120-122]. PKC activity in AD membrane samples prepared from frontal and temporal cortical regions is abnormally low compared to that of age-matched controls [119, 123].

\section{Al inhibits PKC activity in neural cells in a concentration-dependent manner}

$\mathrm{Al}$ inhibition of $\mathrm{PIP}_{2}$ hydrolysis reduces the amount of DAG that forms from this reaction. PKC activity is abnormally low in the cortex of rats chronically exposed to $\mathrm{Al}$ despite an increase in PKC translocation from the soluble fraction to the particulate fraction [124]. Al-treated rats have $31 \%$ of their PKC distributed in the soluble fraction and $67 \%$ in the particulate fraction compared to non-Al-exposed controls 
that have $43 \%$ of their cortical PKC distributed in the soluble fraction and $57 \%$ in the particulate fraction [124].

In addition to $\mathrm{Al}$ effects on brain PKC activity via phosphoinositide signaling pathways, $\mathrm{Al}$ has a direct inhibitory effect on PKC $[125,126]$. Exposure of a rat brain extract of fully-activated PKC to nanomolar amounts of Al reduces PKC activity by $90 \%$ [125]. Sequence studies of PKC have revealed at least three sites in its catalytic domain that are potentially susceptible to modification by Al [126]. These include the $\mathrm{Mg}^{2+}$-ATP binding site, the DAG binding site and the $\mathrm{Ca}^{2+}$ binding site (a carboxyl group). An examination of $\mathrm{Al}$ interaction with soluble $\mathrm{PKC}$ has shown that $\mathrm{Al}$ severely inhibits PKC activity by successfully competing with $\mathrm{Mg}^{2+}$ for ATP and also by blocking $\mathrm{Ca}^{2+}$ binding to the carboxyl group on PKC [125].

PKC activity declines in brains of rats given $10 \mathrm{mg}$ $\mathrm{Al} / \mathrm{kg}$ bw/day by intraperitoneal (i.p.) injection for 4 weeks, to $52 \%$ of the control value in the cerebral cortex, $54 \%$ in the hippocampus, and $61 \%$ in the striatum [51]. In vitro, 10-100 $\mu \mathrm{M} \mathrm{Al}$ inhibits PKC activity, both in cytosolic and in membrane fractions of cortical homogenates [51, 112], in a concentration-dependent manner between 0 and $100 \mu \mathrm{M} \mathrm{Al}$ with an $\mathrm{IC}_{50}$ estimated at $60 \mu \mathrm{M}$ [110]. PKC transfer of ${ }^{32} \mathrm{P}$ from ATP to histone increasingly diminishes as the $\mathrm{Al}$ concentration is raised from $10 \mu \mathrm{M}$ to $100 \mu \mathrm{M}$ [51]. PKC activity declines linearly over this range from 20 to $8 \mathrm{pM}^{32}$ p. $\mathrm{min}^{-1} \cdot \mathrm{mg}^{-1}$ protein.

These alterations in neural cell PKC activity relate to other important aspects of $\mathrm{AD}$ pathology: acetylcholine deficiency and amyloid formation. Acetylcholine deficiency may, in part, result from the inhibitory effects of $\mathrm{Al}$ on PKC activity [126], because
PKC phosphorylation is required for the functional regulation of choline acetyltransferase (ChAT) [127]. $\mathrm{Al}$ also has inhibitory effects on choline uptake and acetylcholine release [128, 129] and lowers the content of acetyl-coenzyme A available for acetylcholine synthesis in cholinergic cells [129]. These observations could help to explain the large (up to 70\%) reduction in ChAT activity, abnormally low amounts of acetylcholine released, and impaired coupling of muscarinic acetylcholine receptors to $\mathrm{G}$ proteins that occur in $\mathrm{AD}$ [130].

PKC phosphorylation of amyloid- $\beta$ protein precursor $(A \beta P P)$ or $\alpha$-secretase contributes to the formation of $\operatorname{sA} \beta P P \alpha$ in healthy brain tissue [131-135]. Chronic $\mathrm{Al}$ exposure, as an inhibitor of PKC activity [124], stabilizes amyloid- $\beta$ oligomers [136] and increases $\beta$-amyloidogenesis in vitro $[136,137]$ and increases amyloid plaque formation in experimental animal models [138, 139]. Hence, the mechanism that switches A $\beta P P$ metabolism from $\mathrm{AA} \beta \mathrm{PP} \alpha$ to amyloid$\beta$ could involve $\mathrm{Al}$ inhibition of PKC activity (Fig. 4).

$\mathrm{Ca}^{2+}$ release from the endoplasmic reticulum

$\mathrm{Ca}^{2+}$ release from the ER is reduced in aged and $A D$-affected neural cells

$\mathrm{Ca}^{2+}$ released through $\mathrm{IP}_{3}$ and ryanodine receptors, primarily in response to $\mathrm{IP}_{3}$ generated from phosphoinositide signaling pathways, gives rise to $\mathrm{Ca}^{2+}$ signals that take the form of local and global changes in $\mathrm{Ca}^{2+}$ concentration, including $\mathrm{Ca}^{2+}$ spikes and oscillations. Old rats (aged 28 months) have almost 50\% fewer $\mathrm{IP}_{3}$ receptors in their cerebral cortex than young rats (aged 3 months) whereas ryanodine receptor numbers in both age groups appear to be similar [140]. Severe decreases
A

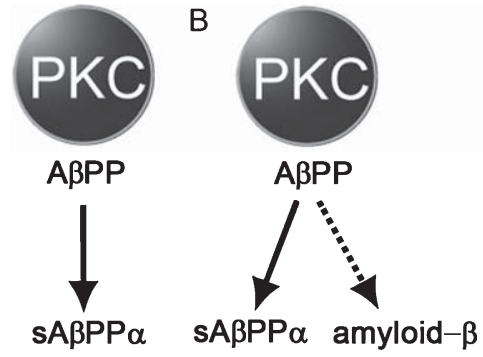

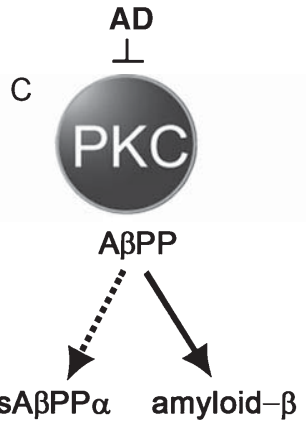

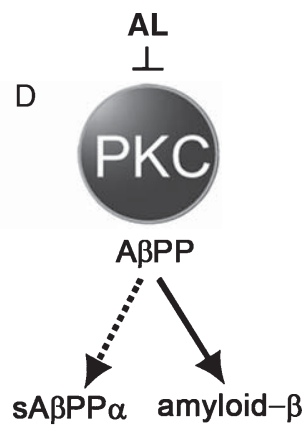

Fig. 4. PKC phosphorylation and A $\beta P P$ metabolism. Schematic diagram depicting A $\beta P P$ processing in young neural cells (A), aged neural cells (B), Alzheimer's disease-affected neural cells (C), and neural cells chronically exposed to Al (D). From left to right, inhibition of PKC activity increases, diverting A $\beta P P$ cleavage from its neuroprotective form ( $\mathrm{A} \beta \mathrm{PP} \alpha$ ) to an aberrant (amyloid- $\beta$ ) form that fibrillizes and accumulates in the extracellular matrix as amyloid plaque. Al exposure produces amyloidogenic effects in brain tissue that expresses the human sequence for amyloid- $\beta$. 
by $50-70 \%$ have been demonstrated in the number of $\mathrm{IP}_{3}$ receptors in AD hippocampal pyramidal cells and/or $\mathrm{IP}_{3}$ receptor binding sites [141-143].

\section{Al inhibits $\mathrm{Ca}^{2+}$ release from the ER in neural cells}

$\mathrm{Al}$ inhibition of $\mathrm{PIP}_{2}$ hydrolysis in turn reduces the amount of $\mathrm{IP}_{3}$ generated from this reaction (Fig. 2B). Chronic exposure of developing rats to $0.3 \% \mathrm{Al}$ in drinking water for 2-3 months inhibits $\mathrm{IP}_{3}$ accumulation in their hippocampus by $15 \%$ [144]. Al interferes with $\mathrm{Ca}^{2+}$ signaling by restricting both $\mathrm{IP}_{3}$-evoked and caffeine-evoked $\mathrm{Ca}^{2+}$ release from ER stores [145]. In vitro observations show that $100 \mu \mathrm{M} \mathrm{Al}$ depresses the frequency of spontaneous and synchronous intracellular $\mathrm{Ca}^{2+}$ oscillations in networks of cortical neurons by $25 \%$ of the control value at day 15 and by $58 \%$ at day 22 of primary culture $[146,147]$. Al exposure also disrupts oscillatory $\mathrm{Ca}^{2+}$ signaling mediated by phosphoinositide signaling pathways in non-neural tissues [e.g., 148].

\section{CaM and CaM-mediated signal transduction}

\section{CaM and CaM-mediated signal transduction are} altered in aged, and even more so in AD-affected, neural cells

$\mathrm{CaM}$ is a major $\mathrm{Ca}^{2+}$ signal transducer that responds to transient changes in cytoplasmic $\mathrm{Ca}^{2+}$ levels by binding to $\mathrm{Ca}^{2+} / \mathrm{CaM}$-dependent protein kinase II (CaMKII) and other CaM-binding protein targets. CaMKII decodes $\mathrm{Ca}^{2+}$ spike and oscillation frequencies, transforming them into discrete quanta of kinase activity [149].

Measurements for $\mathrm{CaM}$ content in the cerebral cortex, striatum, and cerebellum of young (3 monthold), late middle-aged (22 month-old) and old (29-30 month-old) rats show age-related decline in CaM content, most of which occurs between youth and middle age [150-152]. CaM protein content is significantly decreased in AD brains compared to age-matched controls [153].

Aging has parallel effects on CaM activity, reducing its ability to activate target proteins such as plasma membrane $\mathrm{Ca}^{2+}$-ATPase (plasma membrane $\mathrm{Ca}^{2+}$ ATPase pump; PMCA) in older humans [154] and adenylyl cyclase [155] in those with AD. Aging is associated with increased oxidation levels and the $\mathrm{CaM}$ sequence contains easily-oxidizable methionine which could increase $\mathrm{CaM}$ sensitivity to oxidative stress [156].
Conformational monoclonal antibodies raised against $\mathrm{Ca}^{2+} / \mathrm{CaM}$ and CaM (i.e., CAM1 and CAM4, respectively) show that CAM1 immunoreactivity is absent from the AD cortex whereas CAM4 immunoreactivity is less intense in $\mathrm{AD}$ cortex compared to cortex from controls [157]. The changes in CaM levels and $\mathrm{CaM}$ conformations in $\mathrm{AD}$ brain tissue severely impact on the activity of CaM-binding proteins.

O'Day and Myre [158] observe that AD is associated with many proteins with CaM-binding domains that are yet to be recognized as CaM-binding proteins. CaMbinding domains are found in the NMDA receptor protein calcium ion channel, L-type VGCC Ca ${ }^{2+}$ channels, ryanodine receptor channels, adenylyl cyclase II, PI-PLC, neuronal nitric oxide synthase, phosphodiesterase, A $\beta P P$, presenilins 1 and 2, BACE-2, synapsin, tau, and protein phosphatase $2 \mathrm{~B}$ (calcineurin). These proteins are involved in major events pertaining to $\mathrm{Ca}^{2+}$-mediated neuronal function.

\section{Al alters CaM and CaM-mediated signal transduction in neural cells}

$\mathrm{Ca}^{2+}, \mathrm{Mg}^{2+}$, and $\mathrm{Al}^{3+}$ bind to $\mathrm{CaM}$, causing different conformational changes in $\mathrm{CaM}$ as an important mediator of $\mathrm{Ca}^{2+}$ signaling [19, 21, 159]. One article [160] has disputed the original report [161] that Al binds to spin-labeled CaM. However, Al$\mathrm{CaM}$ interactions have since been confirmed by many techniques including the use of steady-state and timedependent fluorescence spectroscopy, circular dicroic spectroscopy, equilibrium dialysis, electron paramagnetic resonance, heteronuclear 2-dimensional NMR, surface plasma resonance, calorimetry, monoclonal antibody (non)recognition and by chelation studies using citric acid or desferrioxamine B which can both chelate $\mathrm{Al}$ and reverse the effects of $\mathrm{Al}$ on $\mathrm{CaM}$ conformational change that occurs with $\mathrm{Al}$ exposure [157, 159, 162-169]. These studies and others have helped to define conditions under which $\mathrm{Al}$ binds to $\mathrm{CaM}$, and how $\mathrm{Al}$ interferes with signal transduction.

${ }^{1} \mathrm{H}^{15} \mathrm{~N}$ heteronuclear single quantum correlation spectroscopic studies have shown that $\mathrm{Al}$ binding occurs in three regions of $\mathrm{CaM}$, in both domains and in the middle of CaM's central helix [159]. Al interaction with $\mathrm{CaM}$ causes subtle, small-scale, change in CaM conformation. When CaM binds to a target its central helix bends to hold the target between the globular domains of CaM. Al binding to the central helix alters its structural flexibility, reducing CaM's affinity for its targets [159]. The monoclonal antibody CAM-1 fails to recognize $\mathrm{CaM}$ that has bound $\mathrm{Al}$ [157]. The 
monoclonal antibody CAM-4, which normally recognizes $\mathrm{CaM}$ with or without bound $\mathrm{Ca}^{2+}$, recognizes epitopes on the terminal lobes. In the presence of $\mathrm{Al}$, CAM-4 recognises CaM complexes bound to some target proteins (e.g., calcineurin), partially recognizes CaM-binding to other target proteins (e.g., phosphodiesterase), and shows little recognition, if any, of CaM-binding to yet other proteins (e.g., mastoparan) [162].

The binding affinity of $\mathrm{Al}$ for $\mathrm{CaM}$ has been estimated to be about one order of magnitude greater for the first mol bound than that of $\mathrm{Ca}^{2+}$ for its equivalent site on $\mathrm{CaM}$ [163]. $\mathrm{Al}^{3+}$ and $\mathrm{Ca}^{2+}$ bind to $\mathrm{CaM}$ at different locations [164]. The solvation structure of $\mathrm{Al} / \mathrm{CaM}$ also appears to be changed, making $\mathrm{Al} / \mathrm{CaM}$ unfavorable for the otherwise proper fit between $\mathrm{CaM}$ and its target proteins. These alterations to $\mathrm{CaM}$ are partially preventable by citrate chelation of Al [165]. Concentrations of $\mathrm{CaM}$ measured in an all-purpose cell strain engineered for high-level protein expression, ranged from 3 to $20 \mu \mathrm{M}$. In vitro exposure of these cells to $100 \mu \mathrm{M} \mathrm{Al}$ reduced their CaM activity to approximately $40 \%$ of its control value [159].

CaM- and cAMP-mediated synaptic events play important roles in memory and learning [170]. Animals with chronic $\mathrm{Al}$ exposure show marked decrease in both CaM and CaMKII activity levels in their brains [166]. CaM efficacy for activating CaMKII and phosphodiesterase in brains of Al-treated rats and rabbits declined progressively to approximately $1 / 2$ and $1 / 3$ of their control values, respectively [51, 54]. Exogenous CaM-stimulated CaMKII activity in Al-exposed animals fell by $45 \%$ in the cerebral cortex, $42 \%$ in the hippocampus, and $23 \%$ in the striatum [166]. CaM's ability to stimulate cAMP-dependent phosphodiesterase decreased maximally in the hippocampus (to $37 \%$ ), then the cortex (32\%), followed by the striatum $(23 \%)$ [166]. Other types of experiments have also shown Al inhibition of cAMP [171, 172]. Given that Al is a pro-oxidant, at least part of Al's inhibitory effects on CaM could be due to oxidative damage which has been shown to alter the activation and regulation of CaMKII, thus disrupting $\mathrm{Ca}^{2+}$ signal decoding [173].

\section{RESTORATION OF CA ${ }^{2+}$ TO ITS RESTING LEVEL}

\section{Mechanisms that restore the resting $\mathrm{Ca}^{2+}$ level are impaired in aged and AD-affected neural cells}

Calbindin, calretinin, and parvalbumin normally bind and sequester excess cytoplasmic $\mathrm{Ca}^{2+}$ [174].
These $\mathrm{Ca}^{2+}$-buffering proteins contribute to restoration of the resting $\mathrm{Ca}^{2+}$ level in neurons after action potentials. Much of the excess $\mathrm{Ca}^{2+}$ is removed from neuronal cytoplasm by $\mathrm{Ca}^{2+}$-ATPases that either pump $\mathrm{Ca}^{2+}$ into the ER stores (sarco/endoplasmic reticulum $\mathrm{Ca}^{2+}$-ATPase, SERCA) or extrude $\mathrm{Ca}^{2+}$ into the extracellular matrix (PMCA) [175]. PMCA activity is supplemented by $\mathrm{Na}^{+}-\mathrm{Ca}^{2+}$ exchange when the intracellular $\mathrm{Ca}^{2+}$ concentration is highly elevated [175]. Mitochondria also take up cytoplasmic $\mathrm{Ca}^{2+}$ but this is conditional upon their proximity to certain regions of the ER.

The time required to completely restore cytoplasmic $\mathrm{Ca}^{2+}$ to its resting level after neural activity is up to ten times longer $(p<0.0001)$ in neurons from old animals than from young animals [176]. Several age-related changes impede $\mathrm{Ca}^{2+}$ removal from the neuronal cytoplasm. For one, the content and/or activity of $\mathrm{Ca}^{2+}$-buffering proteins, particularly calbindin, calretinin, and parvalbumin, progressively decline with age without loss of the relevant cells [177-182]. Also, there are age-related reductions in $\mathrm{Ca}^{2+}$-ATPase activity. For example, PMCA activity levels are significantly lower in central nervous system synaptosomal membranes prepared from brains of old animals than from their young counterparts [183-187]. Another consideration is that PMCA activity is sensitive to oxidative stress which is known to accompany aging [183].

In $\mathrm{AD}$, there are significant decreases in calbindin mRNA and protein in the nucleus basalis, hippocampus, and nucleus raphe dorsalis [177]. Calbindin-D28K protein content has been shown to decline from $312 \mu \mathrm{g} . \mathrm{g}^{-1}$ protein in corticolimbic tissue of age-matched controls to $228 \mu \mathrm{g} . \mathrm{g}^{-1}$ protein in AD corticolimbic tissue [153].

PMCA activity is also significantly altered in AD. Isolated membrane from the temporal cortex of healthy controls shows that free $\mathrm{Ca}^{2+}$ normally stimulates total $\mathrm{Ca}^{2+}$-ATPase activity in the $\mathrm{pCa}$ (free $\mathrm{Ca}^{2+}$ concentration) range between 7.5 and 5.5 and inhibits total $\mathrm{Ca}^{2+}$-ATPase activity in the $\mathrm{pCa}$ range between 5.5 and 3.0. Maximal activity occurs at pCa $5.5(3.16 \mathrm{mM}$ free $\mathrm{Ca}^{2+}$ ) [188]. This $\mathrm{Ca}^{2+}$ dependence hinges on $\mathrm{Ca}^{2+}$ binding to four transport sites on the $\mathrm{Ca}^{2+}$ ATPase protein [189]. $\mathrm{Ca}^{2+}$-ATPase of membranes from the temporal cortex of AD subjects lacks this bellshaped $\mathrm{Ca}^{2+}$ dependent activity, exhibiting instead much broader, flat-topped activity reaching maximum activity at pCA $6.5\left(0.316 \mathrm{mM}\right.$ free $\left.\mathrm{Ca}^{2+}\right)$ that continues up to pCa 3.75 , indicating significant impairment for $\mathrm{Ca}^{2+}$ transport. 
SERCA and secretory protein $\mathrm{Ca}^{2+}$-ATPase (SPCA) exhibit normal $\mathrm{Ca}^{2+}$-dependence and activity in the $\mathrm{AD}$ membrane samples. However, PMCA activity resembles that seen with total $\mathrm{Ca}^{2+}$-ATPase activity, indicating that (1) change in PMCA activity in $\mathrm{AD}$ brain tissue accounts for most impairment observed in the total $\mathrm{Ca}^{2+}$-ATPase activity; and (2) PMCA has lost its dependence on $\mathrm{Ca}^{2+}$ [188].

\section{Al alters mechanisms that restore the resting $\mathrm{Ca}^{2+}$ level in neural cells}

Al accumulation in neurons coincides with agerelated changes that slow $\mathrm{Ca}^{2+}$ removal from the cytoplasm. Al reduces the expression of the $\mathrm{Ca}^{2+}$-buffering protein calbindin-D28K and its mRNA [190, 191]. This effect has mainly been studied in the intestine where $\mathrm{Al}$ reduces $\mathrm{Ca}^{2+}$ absorption by inhibiting calbindin-D28K synthesis [192]. Acute Al exposure inhibits ${ }^{45} \mathrm{Ca}^{2+}$ uptake and sequestration into mitochondria in a concentration-dependent manner [193] whereas $\mathrm{Ca}^{2+}$ release from mitochondrial suspensions occurs at an abnormally rapid rate in the presence of $50 \mu \mathrm{M} \mathrm{Al}$ [194]. Acute Al exposure also stimulates SERCA activity while inhibiting ${ }^{45} \mathrm{Ca}^{2+}$ transport into microsomes [195, 196]. Al strongly inhibits $\mathrm{Ca}^{2+}$ transport by microsomal enzyme pumps in a dose-dependent manner (at $0-100 \mu \mathrm{M}$ Al lactate) with $25 \mu \mathrm{M} \mathrm{Al}$ producing $50 \%$ inhibition of SERCA activity [194].

Chronic oral Al exposure significantly decreases total $\mathrm{Ca}^{2+}$-ATPase activity in primate brain [51], disrupting $\mathrm{Ca}^{2+}$ transport from the cytoplasm. In monkeys, a 30\% decline in this activity has been shown in the cerebral cortex $(p<0.001)$, followed by $23 \%$ in the hippocampus $(p<0.001)$, and $16 \%$ in the striatum $(p<0.001)$. Chronic Al gavage decreases PMCA activity in the rat cerebral cortex by $22 \%(p<0.05)$ and in the hippocampus by $27 \%(p<0.001)$ [48].

$\mathrm{Ca}^{2+}$-ATPase measured in synaptosomes exposed to $\mathrm{Al}$ at concentrations ranging from 0 to $100 \mu \mathrm{M}$ showed a dose-dependent reduction in their PMCA activity with the $\mathrm{IC}_{50}$ at $10 \mu \mathrm{M}$ Al. Moreover, the synaptosomes showed decrease in their ${ }^{45} \mathrm{Ca}^{2+}$ uptake when exposed to both polarizing and de-polarizing media [51, 80]. Exogenously added desferrioxamine (a chelator that removes $\mathrm{Al}$ and $\mathrm{Fe}^{3+}$ ) almost completely restored PMCA activity [51].

These studies demonstrate that low $\mathrm{Al}$ doses effectively disrupt PMCA activity, prevent $\mathrm{Ca}^{2+}$ removal, and contribute to the 2 -fold increase in resting $\mathrm{Ca}^{2+}$ levels observed in cortical and hippocampal tissue of
Al-treated rats relative to controls. Al effects on PMCA activity appear to be similar to those resulting after RNA-induced silencing of the PMCA2 isoform in neurons [197]. Under the latter condition, SERCA, SPCA, and $\mathrm{Ca}^{2+}$-buffering proteins were unable to adequately compensate for the loss of PMCA activity, leading to disruption in $\mathrm{Ca}^{2+}$ homeostasis and signaling.

There are several mechanisms by which $\mathrm{Al}^{3+}$ could inhibit $\mathrm{Ca}^{2+}$ transport. First, Al disrupts the phospholipid bilayer, impairing membrane receptors and their $\mathrm{Ca}^{2+}$ channels [198], and significantly inhibiting the fast phase of voltage-dependent ${ }^{45} \mathrm{Ca}^{2+}$ uptake [51, 80]. Second, $\mathrm{Al}^{3+}$ may act as a competitive inhibitor of $\mathrm{Ca}^{2+}$ for the $\mathrm{Ca}^{2+}$-binding sites on $\mathrm{Ca}^{2+}$-ATPase [51]. $\mathrm{Al}^{3+}$ directly displaces $\mathrm{Ca}^{2+}$ from its phospholipid binding sites on membranes [198] and may also displace $\mathrm{Ca}^{2+}$ at the four binding sites on PMCA normally destined for $\mathrm{Ca}^{2+}$ transport [189]. Third, $\mu \mathrm{M}$ concentrations of $\mathrm{Al}$ compete with $\mathrm{Ca}^{2+}$ for phosphate needed for $\mathrm{Ca}^{2+}$-ATPase activity $[14,198]$. Fourth, $\mathrm{Al}^{3+}$ can substitute for $\mathrm{Mg}^{2+}$ in the $\mathrm{Mg}^{2+}$-ATP cofactor, forming Al-ATP, a dead-end inhibitor for $\mathrm{Ca}^{2+}$-ATPases $[14,23]$. Finally, as PMCA is a CaM-regulated protein [175], Al-induced change in the conformation of $\mathrm{CaM}$ could prevent $\mathrm{CaM}$ from binding in a physiological manner with PMCA and other CaM-binding proteins important to $\mathrm{Ca}^{2+}$ homeostasis and signaling [51, 162].

One other family of AD-related proteins has been implicated in $\mathrm{Ca}^{2+}$ homeostasis and that is the presenilins.

\section{PRESENILINS}

An inducible variant presenilin isoform is diagnostic for sporadic $A D$

Aberrant forms of presenilin have been reported to alter $\mathrm{Ca}^{2+}$ homeostasis. The nature of this relationship has yet to be determined but, according to Green et al. [199], it appears to involve the SERCA pump activity of $\mathrm{Ca}^{2+}$ from the ER. Others have reported that presenilins function as passive $\mathrm{ER} \mathrm{Ca}^{2+}$ leak channels [200].

The vast majority of humans have sporadic AD. Interestingly, a truncated, alternatively spliced variant of the PS2 gene (PS2V), missing the exon 5 sequence, has been found to occur in brains of humans with sporadic $\mathrm{AD}$. $\mathrm{PS} 2 \mathrm{~V}$ is found in $70 \%$ (21/30) of brains from sporadic AD cases and only 17.6\% (3/17) from elderly non-demented controls. Consequently, PS2V can serve as a diagnostic feature of sporadic AD [201]. 
The aberrantly-spliced isoform of the PS2 gene results in a PS2V-encoded protein that, like wildtype PS2 protein, localizes in membranes of the ER and Golgi complex of pyramidal neurons, particularly those within the CA1 field of the hippocampus and temporal cortex of sporadic AD cases [201].

This abnormal PS2 variant alters the correct folding and maturation of A $\beta P P$. PS2V protein down-regulates the signaling pathway of the unfolded protein response (UPR) and increases the sensitivity of cells to ER stress. Neural cells that express wild-type PS2 show $\mathrm{N}$ - and $\mathrm{O}$-glycosylated forms of A $\beta P P$ within a $20 \mathrm{~min}$ chase period whereas $\mathrm{N}$ - and $\mathrm{O}-$ glycosylated A $\beta P P$ forms were absent from cells expressing PS2V. PS2V causes significant increases in both amyloid- $\beta_{1-40}$ and amyloid- $\beta_{1-42}$. CA1 pyramidal neurons that are highly immunoreactive for PS2V exhibit shrinkage and dendritic dieback. Other CA1 cells appear apoptotic. These findings indicate that aberrant splicing of the PS2 gene is implicated in sporadic AD neuropathology [202].

Neuroblastoma cell lines normally lack this PS2 variant but its expression can be induced by hypoxia, accompanied by a $60 \%$ increase in lipid peroxidation. Pre-treatment with cycloheximide and antioxidants block PS2V formation, indicating that reactive oxygen species (ROS) intermediaries may be important for generating this alternative splice variant of the PS2 gene [201].

Al induces alternate splicing of presenilin 2, giving rise to the PSV variant isoform diagnostic for sporadic $A D$

Several ROS-producing metals were tested to learn whether they might be involved in $\mathrm{PS} 2 \mathrm{~V}$ formation. Neuroblastoma cells were exposed to $\mathrm{FeCl}_{2}, \mathrm{FeCl}_{3}$, $\mathrm{ZnCl}_{2}, \mathrm{CuCl}_{2}, \mathrm{CuSO}_{4}, \mathrm{AlCl}_{3}$, and Al-maltol. Al (both $\mathrm{AlCl}_{3}$ and $\mathrm{Al}$-maltol) was the only one of these metals that consistently produced the PS2V isoform and it did so at low concentrations $(25 \mu \mathrm{M})$, either with or without hypoxia [203].

Al-induced oxidative stress in the ER has also been studied and found to involve apoptotic features similar to those described for AD [204, 205]. The shrinkage of hippocampal CA1 neurons and dieback described in neural cells highly immunoreactive for PS2V indicate microtubule depletion as this same trio of features occurs in chronic Al neurotoxicity, affecting Al-rich neurons both with and without neurofibrillary tangles [109, 206, 207].

\section{IMPACTS OF AL ON CA ${ }^{2+}$ HOMEOSTASIS AND SIGNAL TRANSDUCTION IN NEURAL CELLS}

\author{
A study to test the hypothesis
}

The author hypothesizes that intraneuronal $\mathrm{Al}$ interferes with $\mathrm{Ca}^{2+}$ metabolism in the aged human brain. A test of this hypothesis on humans would need to involve intentional long-term exposure to a neurotoxicant. Clearly, this approach would be impractical and unethical. Instead, an appropriate animal model is needed. Aging in the outbred Wistar rat is an excellent model for human aging and much gerontological work has focused on this research subject. If such animals are raised and maintained into old age on the dietary Al protocols previously described [10, 208], some of them develop cognitive deterioration with AD-related neuropathology [78, 109]. These animals consume a diet with a total dietary Al level in their food and water in amounts equivalent to those routinely consumed by humans from their food and water.

One needs to start with twice as many animals needed for statistical significance in order to allow for sudden deaths. We started our experiments [10, 208] on this basis and were pleased to learn that rat mortality before 28 months was lower than anticipated. The Al treatment commences at physical maturity (at least age 6 months) to insure normal brain development prior to the onset of study. At least two Al dose levels are needed, one equivalent to the high end of the human dietary $\mathrm{Al}$ range and one at the low end of this range to provide a source of controls. Al accumulates in their neurons as the rats age.

The rats should be trained in a behavioral task that assesses memory performance in order to objectively distinguish which of them remain cognitively intact and which show cognitive deterioration in old age. Cognitive deterioration generally becomes evident around age 28 months when using the dietary $\mathrm{Al}$ protocols as described [10, 208]. Reference [208], in its electronic form, includes video sequences of a high Al dose rat performing a T-maze task before and after developing cognitive deterioration.

The author expects that commencement of the additional $\mathrm{Al}$ treatment at age 6 months, instead of age 12 months as previously used, might either cause cognitive deterioration to result earlier and/or in a greater proportion of the animals which should be allowed to live their lives to term; i.e., not subjected to premature sacrifice. Experimental animals that reach the old age equivalent of elderly humans are particularly 
valuable as their neural plasticity and capacity for compensatory repair differs substantially from younger animals [209]. A wealth of studies can be carried out on their brain tissues.

There are at least four major $\mathrm{Ca}^{2+}$ regulatory proteins that are fundamental to the main changes that occur in $\mathrm{Ca}^{2+}$ homeostasis and signaling in the brain during aging and with AD. These are G proteins, PKC, CaM, and PMCA. They are all $\mathrm{Mg}^{2+}$-dependent proteins that are inhibited by $\mathrm{Al}$ in dose-dependent manner. All of these $\mathrm{Ca}^{2+}$ regulatory proteins can be analyzed in each rat brain. It would be useful to make measurements on some rat brains at 6 months to obtain baseline values in young fully-grown rats and at 6 month intervals up to 28-30 months to obtain an overview of Al-induced change in these enzyme values over time.

Biochemical analyses of the protein activities, and determination of their contents in the hippocampus, entorhinal, and/or temporal cortex, with biochemical and immunochemical techniques, might show that one protein exhibits change earlier than the others. It would be very interesting to observe if $\mathrm{Ca}^{2+}$ regulatory protein activities were to fall dramatically in brains of rats that develop cognitive deterioration after consuming $\mathrm{Al}$ at the high dose, especially if this effect were absent in brains of the low $\mathrm{Al}$ dose group that age normally.

Julka et al. [51] have already shown that $\mathrm{Al}$ inhibition of PKC activity is preventable with desferrioxamine (DFO) but the results would be even more meaningful in an animal model that mimics human dietary behavior and human aging. This may reveal that an animal cohort treated with both $\mathrm{Al}$ and DFO (for example), could be rescued from cognitive deterioration. Studies such as those suggested can probe the basis for dementia of the Alzheimer type and treatment of the condition. Recognition of the role of $\mathrm{Al}$ in disrupting $\mathrm{Ca}^{2+}$ homeostasis and signaling should also lead to other techniques for timely $\mathrm{Al}$ removal from the human brain.

\section{CONCLUSIONS}

Humans living in industrialized societies are abundantly exposed to $\mathrm{Al}$ from a variety of sources. Observational studies of brain tissue from older individuals, with and without $\mathrm{AD}$, and from experimental animal models of aging, have shown that $\mathrm{Al}$ progressively appears in neurons, particularly in ADvulnerable brain regions. Al can be readily visualized in aged human hippocampal and cortical neurons of appropriately-stained sections $[13,157]$ and $\mathrm{Al}^{3+}$ has been shown to cause neurotoxic damage at picomolar concentrations [15, 24].

Many of the reviewed studies have shown that intraneuronal $\mathrm{Al}$ gives rise to metabolic changes comparable to those associated with aging as it now occurs. These changes include: 1 ) elevation of the resting $\mathrm{Ca}^{2+}$ and peak $\mathrm{Ca}^{2+}$ levels in neuronal cytoplasm; 2) less $\mathrm{Ca}^{2+}$ influx; 3) a modest inhibition of $\mathrm{PIP}_{2}$ hydrolysis by PI-PLC in phosphoinositide signaling pathways, resulting in less $\mathrm{IP}_{3}$ formation, less $\mathrm{PKC}$ activation; and 4 ) and a slower rate of $\mathrm{Ca}^{2+}$ removal from the cytoplasm. A distinguishing difference between aging and $\mathrm{AD}$ relates to the severity of impairment in the activities of major proteins that regulate $\mathrm{Ca}^{2+}$ metabolism: $\mathrm{G}$ protein, PKC, CaM, and PMCA.

A strength of the data described in the present paper is that the findings pertaining to various aspects of $\mathrm{Al}$ perturbation to $\mathrm{Ca}^{2+}$ homeostasis, signaling pathways, and signal transduction are consistent, form a cohesive body of information, and the results are demonstrable with various soluble Al species, and various animal species, in experimental systems having different levels of complexity: from an in vitro defined system using purified chemicals to in vivo brain tissue from aged humans with sporadic AD.

$\mathrm{Al}$ inhibits the relevant proteins in a dose-dependent manner, so it is possible that age changes in $\mathrm{Ca}^{2+}$ metabolism result from neurotoxic effects of progressive intraneuronal $\mathrm{Al}$ accumulation that appear as subtle cellular changes, comparable to those associated with aging as it now occurs. Critical changes in $\mathrm{Ca}^{2+}$ homeostasis and $\mathrm{Ca}^{2+}$ signaling could occur from the continued accumulation of $\mathrm{Al}$ in neurons as they age, leading to the more extensive and disabling disruptions that affect $\mathrm{Ca}^{2+}$ metabolism in AD.

\section{ACKNOWLEDGMENTS}

The author expresses gratitude to Don BrysonTaylor and Min-Xia Wang for their helpful editorial advice and Dirce Brooke Everett for the artwork.

The author's disclosure is available online (http://www.j-alz.com/disclosures/view.php?id= 1091).

\section{REFERENCES}

[1] Berridge MJ (1993) Inositol triphosphate and calcium signaling. Nature 361, 315-325.

[2] Verity MA (1992) $\mathrm{Ca}^{+}{ }^{+}$-dependent processes as mediators of neurotoxicity. Neurotoxicology 13, 139-138. 
[3] Orrenius S, Nicotera P (1994) The calcium ion and cell death. J Neural Trans Suppl 3, 1-11.

[4] Freissmuth M, Casey PJ, Gilman AG (1989) G proteins control diverse pathways of transmembrane signaling. FASEB $J$ 3, 2125-2131.

[5] Khachaturian ZS (1987) Hypothesis on the regulation of cytosol calcium concentration and the aging brain. Neurobiol Aging 8, 345-346.

[6] Walton JR (2012) Evidence that ingested aluminum additives contained in processed foods and alum-treated drinking water are a major risk factor for Alzheimer's disease. Curr Inorg Chem 2, 19-39.

[7] Markesbery WR, Ehmann WD, Hossain TI, Alauddin M, Goodin DT (1981) Instrumental neutron activation analysis of brain aluminum in Alzheimer disease and aging. Ann Neurol 10, 511-516.

[8] McDermott JR, Smith AI, Iqbal K, Wisniewski HM (1979) Brain aluminum in aging and Alzheimer disease. Neurology 29, 809-813.

[9] Shimizu H, Mori T, Koama M, Sekiya M, Ooami H (1994) A correlative study of the aluminum content and aging changes of the brain in non-demented elderly subjects. Nihon Ronen Igakkai Zasshi 31, 950-960.

[10] Walton JR (2009) Functional impairment in aged rats chronically exposed to human range dietary aluminum equivalents. Neurotoxicology 30, 182-193.

[11] Kowall NW, Pendlebury WW, Kessler JB, Perl DP, Beal MF (1989) Aluminum-induced neurofibrillary degeneration affects a subset of neurons in rabbit cerebral cortex, basal forebrain and upper brainstem. Neuroscience 29, 329337.

[12] Edwardson JA, Ferrier IN, McArthur FK, McKeith IG, McLaughlin I, Morris CM, Mountfort SA, Oakley AE, Taylor GA, Ward MK, Candy JM (1986) Alzheimer's disease and the aluminium hypothesis. In: Aluminium in Chemistry Biology and Medicine Raven Press, New York, 1, pp. 85-96

[13] Walton JR (2006) Aluminum in hippocampal neurons from humans with Alzheimer's disease. Neurotoxicology 27, 385394.

[14] Martin RB (1986) The chemistry of aluminum as related to biology and medicine. Clin Chem 32, 1797-1806.

[15] Macdonald TL, Humphreys WG, Martin RB (1987) Promotion of tubulin assembly by aluminum ion in vitro. Science 236, 183-186.

[16] Ganrot PO (1986) Metabolism and possible health effects of aluminum. Environ Health Perspect 65, 363-441.

[17] Cowan JA, Ed (1995) The Biological Chemistry of Magnesium, VCH Publishers, New York, pp. 1-254.

[18] Cowan JA (2002) Structural and catalytic chemistry of magnesium-dependent enzymes. BioMetals 15, 225-235.

[19] Seamon KB (1980) Calcium- and magnesium-dependent conformational states of calmodulin as determined by nuclear magnetic resonance. Biochemistry 19, 207-215.

[20] Rega AF, Garrahan PJ (1980) Effects of calmodulin on the phosphoenzyme of the $\mathrm{Ca}^{2+}$-ATPase of human red cell membranes. Biochim Biophys Acta 596, 487-489.

[21] Zhu MM, Rempel DL, Zhao J, Giblin DE, Gross ML (2003) Probing $\mathrm{Ca}^{2+}$-induced conformational changes in porcine calmodulin by H/D exchange and ESI-MS: Effect of cations and ionic strength. Biochemistry 42, 15388-15397.

[22] Permyakov EA, Kretsinger RH (2009) Cell signaling, beyond cytosolic calcium in eukaryotes. J Inorg Biochem 103, 77-86.

[23] Trapp GA (1986) Interactions of aluminium with cofactors, enzymes and other proteins. Kidney Int 29, S12-S16.
[24] Miller JL, Hubbard CM, Litman BJ, Macdonald TL (1989) Inhibition of transducin activation and guanosine triphosphatase activity by aluminum ion. J Biol Chem 264, 243-250.

[25] Exley C, Birchall JD (1992) The cellular toxicity of aluminum. J Theor Biol 159, 83-98.

[26] Cox PA (2000) Inorganic Chemistry, Springer-Verlag New York Inc., New York, p. 115.

[27] Exley C (2004) The pro-oxidant activity of aluminum. Free Radic Biol Med 36, 380-387.

[28] Bondy SC, Guo-Ross SX, Pien J (1998) Mechanisms underlying the aluminum-induced potentiation of the pro-oxidant properties of transition metals. Neurotoxicology 19, 65-71.

[29] McDonald LJ, Mamrack MD (1995) Phosphoinositide hydrolysis by phospholipase $\mathrm{C}$ modulated by multivalent cations $\mathrm{La}^{3+}, \mathrm{Al}^{3+}$, neomycin, polyamines, and melittin. J Lipid Med Cell Signal 11, 81-91.

[30] Kumar S (1999) Aluminium-induced biphasic effect. Med Hypothesis 52, 557-559.

[31] Chen L, Liu C-J, Tang M, Li A, Hu X-W, Du Y-M, Shen J-J, Lu Y-L, Heschler J (2005) Action of aluminum on high voltage-dependent calcium current and its modulation by ginkgolide B. Acta Pharmacol Sinica 26, 539-545.

[32] Gilman AG (1987) G proteins: Transducers of receptorgenerated signals. Rev Biochem 56, 615-649.

[33] Shi B, Chou K, Haug A (1993) Aluminium impacts elements of the phosphoinositide signalling pathway in neuroblastoma cells. Mol Cell Biochem 121, 109-118.

[34] Gibson GE, Peterson C (1987) Calcium and the aging nervous system. Neurobiol Aging 8, 329-344.

[35] Martinez A, Vitórica J, Satrústegui J (1988) Cytosolic free calcium levels increase with age in rat brain synaptosomes. Neurosci Lett 88, 336-342.

[36] Reynolds JN, Carlen PL (1987) Diminished calcium currents in aged hippocampal dentate gyrus granule neurons. Brain Res 410, 137-153.

[37] Kirischuk S, Pronchuk N, Verkhratsky A (1992) Measurements of intracellular calcium in sensory neurons of adult and old rats. Neuroscience 50, 947-951.

[38] Kirischuk S, Voitenko N, Kostyuk P, Verkhratsky A (1996) Age-associated changes of cytoplasmic calcium homeostasis in cerebellar granule neurons in situ: Investigation on thin cerebellar slices. Exp Gerontol 31, 475-487.

[39] Verkhratsky A, Shmigol A, Kirischus S, Pronchuk N, Kostyuk P (1994) Age-dependent changes in calcium currents and calcium homeostasis in mammalian neurons. Ann NY Acad Sci 747, 365-381.

[40] Kirischuk S, Verkhratsky A (1996) Calcium homeostasis in aged neurones. Life Sci 59, 451-459.

[41] Das N, Ghosh S (1996) The effect of age on calcium dynamics in rat brain in vivo. Mech Ageing Dev 88, 17-24.

[42] Raza M, Deshpande LS, Blair RE, Carter DS, Sombati S, DeLorenzo RJ (2007) Aging is associated with elevated intracellular calcium levels and altered calcium homeostatic mechanisms in hippocampal neurons. Neurosci Lett 418, $77-81$.

[43] Toescu EC, Verkhratsky A (2007) The importance of being subtle: Small changes in calcium homeostasis control cognitive decline in normal aging. Aging Cell 6, 267-273.

[44] Eckert A, Förstl H, Zerfass R, Oster M, Hennerici M, Müller WE (1998) Changes of intracellular calcium regulation in Alzheimer's disease and vascular dementia. J Neural Transm Suppl 54, 201-210.

[45] Green KN, LaFerla FM (2008) Linking calcium to $A \beta$ and Alzheimer's disease. Neuron 59, 190-194. 
[46] McLachlan DRC (2006) Aluminium and the risk for Alzheimer's disease. Environmetrics 6, 233-275.

[47] Guo-Ross S, Yang E, Bondy SC (1998) Elevation of cerebral proteases after systemic administration of aluminum. Neurochem Int 33, 277-282.

[48] Kaur A, Gill KD (2005) Disruption of neuronal calcium homeostasis after chronic aluminium toxicity in rats. Basic Clin Pharmacol Toxicol 96, 118-122.

[49] Yase Y (1980) The role of aluminum in CNS degeneration with interaction of calcium. In: L. Liss (Ed.), Aluminum Neurotoxicity Pathotox Publ., Park Forest South, IL, USA, pp. 101-109.

[50] Yasui M, Yase Y, Ota K, Garruto RM (1991) Evaluation of magnesium, calcium and aluminum metabolism in rats and monkeys maintained on calcium-deficient diets. Neurotoxicology 12, 603-613.

[51] Julka D, Gill KD (1996) Altered calcium homeostasis: A possible mechanisms of aluminium-induced neurotoxicity. Biochim Biophys Acta 1315, 47-54.

[52] Sarin S, Julka D, Gill KD (1997) Regional alterations in calcium homeostasis in the primate brain following chronic aluminium exposure. Mol Cell Biochem 168, 95-100.

[53] Anghileri LJ (1992) Effects of complexed iron and aluminum on brain calcium. Neurotoxicology 13, 475-478.

[54] Farnell BJ, Crapper McLachlan DR, Baimbridge K, De Boni U, Wong L, Wood PL (1985) Calcium metabolism in aluminum encephalopathy. Exp Neurol 88, 68-83.

[55] Mundy WR, Freudenrich TM, Kodavanti PRS (1997) Aluminum potentiates glutamate-induced calcium accumulation and iron-induced oxygen free radical formation in primary neuronal cultures. Mol Chem Neuropathol 32, 4157.

[56] Guo G-W, Liang Y-X (2001) Aluminum-induced apoptosis in cultured astrocytes and its effect on calcium homeostasis. Brain Res 888, 221-226.

[57] Shi B, Haug A (1992) Aluminium interferes with signal transduction in neuroblastoma cells. Pharmacol Toxicol 71, 308-313.

[58] Garruto RM, Fukatsu R, Yanagihara R, Gajdusek DC, Hook G, Fiori CE (1984) Imaging of calcium and aluminum in neurofibrillary tangle-bearing neurons in parkinsonismdementia of Guam. Proc Natl Acad Sci U S A 81, 1875-1879.

[59] Siesjo BK (1990) Calcium in the brain under physiological and pathological conditions. Eur Neurol 30(Suppl 2), 3-9.

[60] Wenk GL, Barnes CA (2000) Regional changes in the hippocampal density of AMPA and NMDA receptors across the lifespan of the rat. Brain Res $\mathbf{8 8 5}, 1-5$.

[61] Bonhaus DW, Perry WB, McNamara JO (1990) Decreased density, but not number of N-methyl-D-aspartate, glycine and phencyclidine binding sites in hippocampus of senescent rats. Brain Res 532, 82-86.

[62] Ninomiya H, Fukunaga R, Taniguchi T, Fujiwara M, Shimohama S, Kameyama M (1990) $\left[{ }^{3} \mathrm{H}\right] \mathrm{N}-[1-(2-$ thienyl)cyclohexyl]-3,4-piperidine $\left(\left[{ }^{3} \mathrm{H}\right] \mathrm{TCP}\right)$ binding in human frontal cortex: Decreases in Alzheimer-type dementia. J Neurochem 54, 526-532.

[63] Penney JB, Maragos WF, Greenamyre JT, Debowey DL, Hollingsworth Z, Young AB (1990) Excitatory amino acid binding sites in the hippocampal region of Alzheimer's disease and other dementias. J Neurol Neurosurg Psychiatry 53, 313-320.

[64] Ulas J, Brunner LC, Geddes JW, Choe W, Cotman CW (1992) N-methyl-D-aspartate receptor complex in the hippocampus of elderly, normal individuals and those with Alzheimer's disease. Neuroscience 49, 45-61.
[65] Campbell LW, Hao SY, Thibault O, Blalock EM, Landfield PW (1996) Aging changes in voltage-gated calcium currents in hippocampal CA1 neurons. J Neuroscience 16, 6286-6295.

[66] Reynolds JN, Carlen PL (1987) Diminished calcium currents in aged hippocampal dentate gyrus granule neurons. Brain Res 410, 137-153.

[67] Giovannelli L, Giancarlo P (1989) Effect of age on $\mathrm{K}^{+}$-induced cytosolic $\mathrm{Ca}^{2+}$ changes in rat cortical synaptosomes. J Neurochem 53, 392-398.

[68] Peterson C, Gibson GE (1983) Aging and 3,4diaminiopyridine alter synaptosomal calcium uptake. J Biol Chem 258, 11382-11386.

[69] Power JM, Wu WW, Sametsky E, Oh MM, Disterhoft JF (2002) Age-related enhancement of the slow outward calcium-activated current in hippocampal CA1 pyramidal neurons in vitro. J Neurosci 22, 7234-7243.

[70] Moyer JR Jr, Thompson LT, Black JP, Disterhoft JF (1992) Nimodipine increases excitability of rabbit CA1 pyramidal neurons in an age- and concentration-dependent manner. J Neurophysiol 68, 2100-2109.

[71] Nachshen DA (1985) Regulation of cytosolic calcium concentrations in presynaptic nerve endings isolated from rat brain. J Physiol 363, 87-101.

[72] Platt B, Haas H, Busselberg D (1994) Aluminium reduces glutamate-activated currents of rat hippocampal neurones. Neuroreport 5, 2329-2332.

[73] Büsselberg D (1995) Calcium channels as target sites of heavy metals. Toxicol Lett 82, 255-261.

[74] Jin CH, Wu SW, Zhou P, Liu QF, Lu XB, Shi LD, Cai $\mathrm{Y}$ (2010) Effect of aluminum on $\mathrm{Ca}^{2+}$ concentration and expression of phospholipase $\mathrm{C}$ and NMDA receptor $\alpha$ genes in hippocampus of weaning rats as well as their neural behavior through subchronic exposure. Zhonghua Lao Dong Wei Sheng Zhi Ye Bing Za Zhi (Chin J Ind Hyg Occup Dis), 28, 648-651.

[75] Koss DJ, Hindley KP, Riedel G, Platt B (2007) Modulation of hippocampal calcium signalling and plasticity by serine/threonine protein phosphatases. J Neurochem 102, 1009-1023.

[76] Amador FC, Henriques AG, da Cruz e Silva OAB, da Cruz e Silva EF (2004) Monitoring protein phosphatase 1 isoform levels as a marker for cellular stress. Neurotox Teratol 26, 387-395.

[77] Yamamoto H, Saitoh Y, Yasugawa S, Miyamoto E (1990) Dephosphorylation of tau factor by protein phosphatase $2 \mathrm{~A}$ in synaptosomal cytosol fractions, and inhibition by aluminum. J Neurochem 55, 683-690.

[78] Walton JR (2007) An aluminum-based rat model for Alzheimer's disease exhibits oxidative damage, inhibition of PP2A activity, hyperphosphorylated tau, and granulovacuolar degeneration. J Inorg Biochem 101, 12751284.

[79] Cordeiro JM, Silva VS, Oliveira CR, Goncalves PP (2003) Aluminium-induced impairment of $\mathrm{Ca}^{2+}$ modulatory action on GABA transport in brain cortex nerve terminals. J Inorg Biochem 97, 132-132.

[80] Koenig ML, Jope RS (1987) Aluminum inhibits the fast phase of voltage-dependent calcium influx into synaptosomes. J Neurochem 49, 316-320.

[81] Platt B, Busselberg D (1994) Actions of aluminum on voltage-activated calcium channel currents. Cell $\mathrm{Mol} \mathrm{Neu-}$ robiol 13, 819-829.

[82] Provan SD, Yokel RA (1992) Aluminum inhibits glutamate release from transverse rat hippocampal slices: Role of $G$ 
proteins, Ca channels and protein kinase C. Neurotoxicology 13, 413-420.

[83] Busselberg D, Platt B, Haas HL, Carpenter DO (1993) Voltage-gated calcium channel currents of rat dorsal root ganglion (DRG) cells are blocked by $\mathrm{Al}^{3+}$. Brain Res $\mathbf{6 2 2}$, 163-168.

[84] Lai JCK, Blass JP (1984) Inhibition of brain glycolysis by aluminum. J Neurochem 42, 438-446.

[85] Fukuyama R, Wadhwani KC, Galdzicki Z, Rapoport SI, Ehrenstein G (1994) $\beta$-Amyloid polypeptide increases calcium-uptake in PC12 cells: A possible mechanism for its cellular toxicity in Alzheimer's disease. Brain Res 667, 269-272.

[86] Arispe N, Rojas E, Pollard HB (1993) Alzheimer disease amyloid beta protein forms calcium channels in bilayer membranes: Blockade by tromethamine and aluminum. Proc Natl Acad Sci U S A 90, 567-571.

[87] Chandler LJ, Crews FT (1990) Calcium- versus G proteinmediated phosphoinositide hydrolysis in rat cerebral cortical synaptoneurosomes. J Neurochem 55, 1022-1030.

[88] Surichamorn W, Abdallah AM, El-Fakahany EE (1989) Aging does not alter brain muscarinic receptor-mediated phosphoinositide hydrolysis and its inhibition by phorbol esters, tetrodotoxin and receptor desensitization. J Pharmacol Exp Ther 25, 543-549.

[89] Nalepa L, Pintor A, Fortuna S, Vetulani J, Michaelik H (1989) Increased responsiveness of the cerebral cortical phosphatidylinositol system to noradrenaline and carbachol in senescent rats. Neurosci Lett 107, 195-199.

[90] Pietrzak ER, Wilce PA, Shanley BC (1990) Effects of chronic ethanol treatment and aging on brain phophoinositide turnover and adenylate cyclase activity. Neurochem Int 17, 593-598.

[91] Burnett DM, Bowyer JF, Masserano JM, Zahniser NR (1990) Effect of aging on alpha-1 adrenergic stimulation of phosphoinositide hydrolysis in various regions of rat brain. J Pharmacol Exp Ther 255, 1265-1270.

[92] Mundy W, Tandon P, Ali S, Tilson H (1991) Age-related changes in receptor-mediated phosphoinositide hydrolysis in various regions of rat brain. Life Sci 49, PL97PL102.

[93] Gonzales RA, Brown LM, Jones TW, Trent RD, Westbrook SL, Leslie SW (1991) N-methyl-D-aspartate mediated responses decrease with age in Fischer 344 rat brain. Neurobiol Aging 19, 219-225.

[94] Ayyagari PV, Gerber M, Joseph JA, Crewes FT (1998) Uncoupling of muscarinic cholinergic phosphoinositide signals in senescent cerebral cortical and hippocampal membranes. Neurochem Int 32, 107-115.

[95] Nicolle MM, Colombo PJ, Gallagher M, McKinney M (1999) Metabotropic glutamate receptor-mediated hippocampal phosphoinositide turnover is blunted in spatial learning-impaired aged rats. $J$ Neurosci 19, 96049610.

[96] Pintor A, Potenza RL, Domenici MR, Tburzi F, Reggio R, Pezzola A, Popoli P (2000) Age-related decline in the functional response of striatal group $1 \mathrm{mGlu}$ receptors. $\mathrm{Neu}$ roreport 11, 3033-3038.

[97] Domenici MR, Pintor A, Potenza RL, Gaudi S, Gro MC, Passarelli F, Reggio R, Galluzzo M, Massotti M, Papoli P (2003) Metabotropic glutamate receptor 5 (mGluR5)-mediated phosphoinositide hydrolysis and NMDA-potentiating effects are blunted in the striatum of aged rats: A possible additional mechanism in striatal senescence. Eur J Neurosci 17, 2047-2055.
[98] Crews FT, Kurian P, Freund (1994) Cholinergic and serotonergic stimulation of phosphoinositide hydrolysis is decreased in Alzheimer's disease. Life Sci 55, 19932002.

[99] Jope RS, Song L, Li X, Powers R (1994) Impaired phosphoinositide hydrolysis in Alzheimer's disease brain. Neurobiol Aging 15, 221-226.

[100] Greenwood AF, Powers RE, Jope RS (1995) Phosphoinositide hydrolysis, $\mathrm{G}$ alpha $\mathrm{q}$, phospholipase $\mathrm{C}$, and protein kinase $\mathrm{C}$ in post mortem human brain: Effects of post mortem interval, subject age, and Alzheimer's disease. Neuroscience 69, 125-138.

[101] Ferrari-DeLio G, Flynn GG (1993) Diminished muscarinic receptor-stimulated $\left[{ }^{3} \mathrm{H}\right]$-PIP2 hydrolysis in Alzheimer's disease. Life Sci 53, PL439-PL444.

[102] Jope RS (1999) Modulation of phosphoinositide hydrolysis by $\mathrm{NaF}$ and aluminum in rat cortical slices. J Alzheimers Dis 1, 231-247.

[103] Mundy WR, Shafer TJ (2001) Aluminium-induced alteration of phosphoinositide and calcium signalling. In: Aluminium and Alzheimer's Disease: The Science that Describes the Link. Exley C, Ed., Elsevier Science BV Amsterdam, pp. 340-360.

[104] Johnson GV, Jope RS (1986) Aluminum impairs glucose utilization and cholinergic activity in rat brain in vitro. Toxicology 40, 93-102.

[105] Kanaho A, Moss J, Vaughan M (1985) Mechanism of inhibition of transducin GTPase activity by fluoride and aluminum. J Biol Chem 260, 11393-11397.

[106] McDonald LJ, Mamrack MD (1988) Aluminum affects phosphoinositide hydrolysis by phosphoinositidase C. Biochem Biophys Res Comm 155, 203-208.

[107] Nostrandt AC, Shafer TJ, Mundy WR, Padilla S (1996) Inhibition of rat brain phosphatidylinositol-specific phospholipase $\mathrm{C}$ by aluminum: Regional differences, interactions with aluminum salts, and mechanisms. Toxicol Appl Pharmacol 136, 118-125.

[108] Roychowdhury S, Rasenick MM (1994) Tubulin-G protein association stabilizes GTP binding and activates GTPase: Cytoskeletal participation in neuronal signal transduction. Biochemistry 33, 9800-9805.

[109] Walton JR (2009) Brain lesions comprised of aluminumrich cells that lack microtubules may be associated with the cognitive deficit of Alzheimer's disease. Neurotoxicology 30, 1059-1069.

[110] Jope RS, Song L, Powers RE (1997) Cholinergic activation of phosphoinositide signaling is impaired in Alzheimer's disease brain. Neurobiol Aging 18, 111-120.

[111] Shafer TJ, Nostrandt AC, Tilson HA, Mundy WR (1994) Mechanisms underlying $\mathrm{AlCl}_{3}$ inhibition of agoniststimulated inositol phosphate accumulation. Role of calcium, G-proteins, phospholipase $\mathrm{C}$ and protein kinase $\mathrm{C}$. Biochem Pharmacol 47, 1317-1325.

[112] Shafer TJ, Mundy WR, Tilson HA (1993) Aluminum decreases muscarinic, adrenergic, and metabotropic receptor-stimulated phosphoinositide hydrolysis in hippocampal and cortical slices from rat brain. Brain Res 629 , 133-140.

[113] Mundy WR, Freudenrich T, Shafer TJ, Nostrandt AC (1995) In vitro aluminum inhibition of brain phosphoinositide metabolism: Comparison of neonatal and adult rats. Neurotoxicology 16, 35-44.

[114] Wood PC, Wojcikiewicz RJH, Burgess J, Castleden CM, Nahorski SR (1994) Aluminum inhibits muscarinic agonistinduced inositol 1,4,5-triphosphate production and calcium 
mobilization in permeabilized SH-SY5Y human neuroblastoma cells. J Neurochem 62, 2219-2223.

[115] Verstraeten SV, Oteiza PI (2002) $\mathrm{Al}^{3+}$-mediated changes in membrane physical properties participate in the inhibition of polyphosphoinositide hydrolysis. Arch Biochem Biophys 408, 263-271.

[116] Verstraeten SV, Villaverde MS, Oteiza PI (2003) $\mathrm{Al}^{3+}$ mediated changes on membrane fluidity affects the activity of PI-PLC but not of PLC. Chem Phys Lipids 122, 159-163.

[117] Jones DL, Kochian LV (1995) Aluminum inhibition of the inositol 1,4,5-triphosphate signal transduction pathway in wheat roots: A role in aluminium toxicity? Plant Cell 7 1913-1922.

[118] McCullar JS, Malencik DA, Vogel WK, Crofoot KM, Anderson SR, Filtz TM (2007) Calmodulin potentiates G $\gamma \gamma$ activation of phospholipase C- $\beta 3$. Biochem Pharmacol 73, 270-278.

[119] Johnson GVW, Cogdill KW, Jope RS (1990) Oral aluminum alters in vitro protein phosphorylation and kinase activities in rat brain. Neurobiol Aging 11, 209-216.

[120] Friedman E, Wang HY (1989) Effect of age on brain cortical protein kinase $\mathrm{C}$ and its mediation of 5-hydroxytryptamine release. J Neurochem 52, 187-192.

[121] Battaini F, Del Vesco R, Govoni S, Trabucchi M (1990) Regulation of phorbol ester binding and protein kinase $\mathrm{C}$ activity in aged rat brain. Neurobiol Aging 11, 563-566.

[122] Magnoni MS, Govoni S, Battaini F, Trabucchi M (1991) The ageing brain: Protein phosphorylation as a target of changes in neuronal function. Life Sci 48, 373-385.

[123] Cole G, Dobkins KR, Hansen LA, Terry RD, Saitoh T (1988) Decreased levels of protein kinase $\mathrm{C}$ in Alzheimer disease. Brain Res 452, 165-174.

[124] Wang H-Y, Pisano MR, Friedman E (1994) Attenuated protein kinase $\mathrm{C}$ activity and translocation in Alzheimer's disease brain. Neurobiol Aging 15, 293-298.

[125] Cochran M, Elliott DC, Brennan P, Chawtur V (1990) Inhibition of protein kinase $\mathrm{C}$ activation by low concentrations of aluminium. Clin Chim Acta 194, 167-172.

[126] Katsuyama H, Saijoh K, Inoue Y, Sumino K (1998) The interaction of aluminium with soluble protein kinase $\mathrm{C}$ from mouse brain. Arch Toxicol 63, 474-478.

[127] Dobransky T, Davis WL, Rylett RJ (2001) Functional characterization of phosphorylation of $69-\mathrm{kDa}$ human choline acetyltransferase at serine 440 by protein kinase C. $J$ Biol Chem 276, 22244-22250.

[128] Silva VS, Nunes MA, Cordeiro JM, Calejo AI, Santos S, Neves P, Sykes A, Morgado F, Dunant Y, Gonçalves PP (2007) Comparative effects of aluminum and ouabain on synaptosomal choline uptake, acetylcholine release and (Na+/K+) ATPase. Toxicology 236, 58-77.

[129] Szutowicz A, Tomaszewicz M, Jankowska A, Madziar B, Bielarczyk H (2000) Acetyl-CoA metabolism in cholinergic neurons and their susceptibility to neurotoxic inputs. Metab Brain Dis 15, 29-44.

[130] Hansen LA, DeTeresa R, Davies P, Terry RD (1988) Neocortical morphometry, lesion counts, and choline acetyltransferase levels in the age spectrum of Alzheimer's disease. Neurology 38, 48-54.

[131] Gandy S, Greengard P (1994) Regulated cleavage of the Alzheimer amyloid precursor protein: Molecular and cellular basis. Biochimie 76, 300-303.

[132] Hung AY, Haass C, Nitsch RM, Qui WWQ, Citron M, Wurtman RJ, Growdon JH, Selkoe DJ (1993) Activation of protein kinase $\mathrm{C}$ inhibits cellular production of the amyloid ß-protein. J Biol Chem 268, 22959-22962.
[133] Gandy S, Czernik AJ, Greengard P (1988) Phosphorylation of Alzheimer disease amyloid precursor protein peptide by protein kinase $\mathrm{C}$ and $\mathrm{Ca}^{2+}$ /calmodulin-dependent protein kinase II. Proc Natl Acad Sci U S A 85, 62186221.

[134] Caporaso GL, Gandy SE, Buxbaum JD, Ramabhadran TV, Greengard P (1992) Protein phosphorylation regulates secretion of Alzheimer $\beta / A 4$ amyloid precursor protein. Proc Natl Acad Sci U S A 89, 3055-3059.

[135] Nitsch RM, Growdon RJ (1994) Role of neurotransmission in the regulation of amyloid beta-protein precursor processing. Biochem Pharm 47, 1275-1284.

[136] Drago D, Cavaliere A, Mascetra N, Ciavardelli D, di Ilio C, Zatta P, Sensi SL (2008) Aluminum modulates effects of beta amyloid(1-42) on neuronal calcium homeostasis and mitochondria functioning and is altered in a triple transgenic mouse model of Alzheimer's disease. Rejuv Res 11, 861-871.

[137] Kawahara M, Muramoto K, Kobayashi K, Mori H, Kuroda Y (1994) Aluminum promotes the aggregation of Alzheimer's amyloid beta-protein in vitro. Biochem Biophys Res Commun 198, 531-535.

[138] Pratico D, Uryu K, Sung S, Tang S, Trojanowski JW, Lee VM-Y (2002) Aluminum modulates brain amyloidosis through oxidative stress in APP transgenic mice. FASEB J 16, 1138-1131.

[139] Banks WA, Niehoff ML, Drago D, Zatta P (2006) Aluminum complexing enhances amyloid beta protein penetration of blood brain barrier. Brain Res 1116, 115-221.

[140] Martini A, Battaini F, Govoni S, Volpe P (1994) Inositol 1,4,5-trisphosphate receptor and ryanodine receptor in the aging brain of Wistar rats. Neurobiol Aging 15, 203-206.

[141] Young LT, Kish SJ, Li PP, Warch J (1988) Decreased brain $\left[{ }^{3} \mathrm{H}\right]$ inositol 1,4,5-triphosphate binding in Alzheimer's disease. Neurosci Lett 94, 198-202.

[142] Garlind A, Cowburn RF, Forsell C, Ravid R, Winblad B, Fowler CJ (1995) Diminished $\left[{ }^{3} \mathrm{H}\right]$ inositol $(1,4,5) \mathrm{P} 3$ but not $\left[{ }^{3} \mathrm{H}\right]$ inositol $(1,3,4,5) \mathrm{P} 4$ binding in Alzheimer's disease brain. Brain Res $\mathbf{6 8 1}, 160-166$.

[143] Haug LS, Øestvold AD, Cowburn RF, Garlind A, Winblad B, Bogdanovich N, Walaas SJ (1996) Decreased inositol (1,4,5)-triphosphate receptor levels in Alzheimer's disease cerebral cortex: Selectivity of changes and possible correlation to pathological severity. Neurodegeneration $\mathbf{5}$, 169-176.

[144] Johnson GV, Watson AL Jr, Lartius R, Uemura E, Jope RS (1992) Dietary aluminum selectively decreases MAP-2 in brains of developing and adult rats. Neurotoxicology 13, 463-474.

[145] Wakui M, Itaya K, Birchall D, Petersen OH (1990) Intracellular aluminium inhibits acetylcholine- and caffeine-evoked $\mathrm{Ca}^{2+}$ mobilization. FEBS Lett 267, 301-304.

[146] Kawahara M, Muramoto K, Kobayashi K, Mori H, Kuroda Y (1992) Aluminum promotes the aggregation of Alzheimer's amyloid B-protein in vitro. Biochem Biophys Res Commun 189, 1317-1322.

[147] Kuroda Y, Kobayashi K, Ichikawa M, Kawahara M, Muramoto K (1995) Application of long-term cultured neurons in aging and neurological research: Aluminum neurotoxicity, synaptic degeneration and Alzheimer's disease. Gerontology 41(Suppl 1), 2-6.

[148] Schöfl C, Sanchez-Bueno A, Dixon CJ, Woods NM, Lee JA, Cuthbertson KS, Cobbold PH, Birchall JD (1990) Aluminium perturbs oscillatory phosphoinositide-mediated 
calcium signalling in hormone-stimulated hepatocytes. Biochem J 269, 547-550.

[149] De Koninck P, Schulman H (1998) Sensitivity of CaM kinase II to the frequency of $\mathrm{Ca}^{2+}$ oscillations. Science 179, 227-230.

[150] Hoskins B, Scott JM (1984) Changes in activities of calmodulin-mediated enzymes in rat brain during aging. Mech Aging Dev 26, 231-239.

[151] Teolato S, Calderini G, Bonetti AC, Toffano G (1983) Calmodulin content in different brain areas of aging rats. Neurosci Lett 38, 57-60.

[152] Levine AS, Gosnell BA, Morley JE (1986) Alterations in calmodulin levels in tissues from aged animals. J Gerontol 41, 20-23.

[153] McLachlan DR, Wong L, Bergeron C, Baimbridge KG (1987) Calmodulin and calbindin D28K in Alzheimer disease. Alzheimer Dis Assoc Disord 1, 171-179.

[154] Gao J, Yin D, Yao Y, Williams TD, Squier TC (1998) Progressive decline in the ability of calmodulin isolated from aged brain to activate the plasma membrane Ca-ATPase. Biochemistry 37, 9536-9548.

[155] Yamamoto M, Gotz ME, Ozawa H, Luckhaus C, Saito T, Rosler M, Riederer P (2000) Hippocampal level of neural specific adenylyl cyclase type I is decreased in Alzheimer's disease. Biochim Biophys Acta 1535, 60-68.

[156] Yao Y, Yin D, Jas GS, Kuczer K, Williams TD, Schoneich C, Squier TC (1996) Oxidative modification of a carboxyl-terminal vicinal methionine in calmodulin by hydrogen peroxide inhibits calmodulin-dependent activation of the plasma membrane Ca-ATPase. Biochemistry 35, 2767-2787.

[157] Solomon B, Koppel R, Jossiphov J (2001) Immunostaining of calmodulin and aluminium in Alzheimer's diseaseaffected brains. Brain Res Bull 55, 253-256.

[158] O'Day D, Myre MA (2004) Calmodulin-binding domains in Alzheimer's disease proteins: Extending the calcium hypothesis. Biochem Biophys Res Commun 320, 1051-1054.

[159] Kurita H, Nakatomi A, Shimahara H, Yazawa M, Ohki S$\mathrm{Y}(2005) \mathrm{Al}^{3+}$ interaction sites of calmodulin and the $\mathrm{Al}^{3+}$ effect on target binding of calmodulin. Biochem Biophys Res Commun 333, 1060-1065.

[160] You G, Nelson DJ (1991) $\mathrm{Al}^{3+}$ versus $\mathrm{Ca}^{2+}$ ion binding to methionine and tyrosine spin-labeled bovine brain calmodulin. J Inorg Biochem 41, 283-291.

[161] Siegel N, Coughlin R, Haug A (1983) A thermodynamic and electron paramagnetic resonance study of structural changes in calmodulin induced by aluminium binding. Biochem Biophys Res Commun 115, 512-517.

[162] Wolf T, Solomon B, Ivnitski D, Rishpon J, Fleminger G (1998) Interactions of calmodulin with metal ions and with its target proteins revealed by conformation-sensitive monoclonal antibodies. J Mol Recogn 11, 13-19.

[163] Siegel N, Haug A (1983) Aluminum interaction with calmodulin. Evidence for altered structure and function from optical and enzymatic studies. Biochim Biophys Acta 744, 36-45.

[164] Weis C, Haug A (1987) Aluminum-induced conformational changes in calmodulin alter the dynamics of interaction with melittin. Arch Biochem Biophys 254, 304-312.

[165] Suhayda CG, Haug A (1984) Organic acids prevent aluminium-induced conformational changes in calmodulin. Biochem Biophys Res Comm 119, 376-381.
[166] Julka D, Gill KD (1996) Involvement of altered cytoskeletal protein phosphorylation in aluminium-induced CNS dysfunction. J Biochem Toxicol 11, 227-233.

[167] Richardt G, Federolf G, Habermann E (1985) The interaction of aluminum and other metal ions with calciumcalmodulin-dependent phosphodiesterase. Arch Toxicol 57, 257-259.

[168] Julka D, Gill KD (1996) Altered calcium homeostasis: A possible mechanism of aluminium-induced neurotoxicity. Biochim Biophys Acta 1315, 47-54.

[169] Vig PJ, Nath R, Desaiah D (1989) Metal inhibition of calmodulin activity in monkey brain. J Appl Toxicol 9, 313-316.

[170] Ali M, Bullock S, Rose PR (1988) Phosphorylation of synaptic proteins in chick forebrain: Changes with development and passive avoidance training. J Neurochem 50, 1579-1587.

[171] Johnson GV, Li XH, Jope RS (1989) Aluminum increases agonist-stimulated cyclic AMP production in rat cerebral cortical slices. J Neurochem 53, 258-263.

[172] Johnson GVW, Jope RS (1987) Aluminum alters cyclic AMP and cyclic GMP levels but not presynaptic cholinergic markers in rat brain in vivo. Brain Res 403, 1-6.

[173] Robison AJ, Winder DG, Colbran RJ, Bartlett RK (2007) Oxidation of calmodulin alters activation and regulation of CAMKII. Biochem Biophys Res Commun 356, 97-101.

[174] Hof PR, Rosenthal RE, Fiskum G (1996) Distribution of neurofilament protein and calcium-binding proteins parvalbumin, calbindin, and calretinin in the canine hippocampus. J Chem Neuroanat 11, 1-12.

[175] Blaustein MP (1988) Calcium transport and buffering in neurons. Trends Neurosci 11, 438-443.

[176] Kirischuk S, Pronchuk N, Verkhratsky A (1992) Measurements of intracellular calcium in sensory neurons of adults and old rats. Neuroscience 50, 947-951.

[177] Iaocopino AM, Christakos S (1990) Specific reduction of calcium-binding protein (28-kilodalton calbindin-D) gene expression in aging and neurodegenerative diseases. Proc Natl Acad Sci U S A 87, 4078-4082.

[178] Villa A, Podini P, Panzeri MC, Racchetti G, Meldolesi J (1994) Cytosolic $\mathrm{Ca}^{2+}$ binding proteins during rat brain ageing: Loss of calbindin and calretinin in the hippocampus, with no change in the cerebellum. Eur J Neurosci 6, 1391-1399.

[179] Krzywkowski P, De Bilbao F, Senut MC, Lamour Y (1995) Age-related changes in parvalbumin- and GABAimmunoreactive cells in the rat septum. Neurobiol Aging 16, 29-40.

[180] Kishimoto J, Tsuchiya T, Cox H, Emson PC, Nakayama Y (1998) Age-related changes of calbindin-D28k, calretinin, and parvalbumin mRNAs in the hamster brain. Neurobiol Aging 19, 77-82.

[181] Geula C, Nagykery N, Wu C-K, Bu Jing (2003) Loss of calbindin-D28K from aging human cholinergic basal forebrain: Relation to plaques and tangles. J Neuropathol Exp Neurol 62, 605-616.

[182] Choi JH, Hwang IK, Yoo KY, Yi SS, Park OK, Lee CH, Yoon YS, Won MH (2009) Reduction of calbindin D-28kimmunoreactive neurons in the dog dentate gyrus. J Vet Med Sci 71, 1125-1128.

[183] Mundy WR, Kodavanti PR, Dulchinos VF, Tilson HA (1994) Aluminum alters calcium transport in plasma membrane and endoplasmic reticulum from rat brain. $J$ Biochem Toxicol 9, 17-23. 
[184] Zaidi A, Gao J, Squier TC, Michaelis ML (1998) Agerelated decrease in brain synaptic membrane Ca-ATPase in F344/BNF1 rats. Neurobiol Aging 19, 487-495.

[185] Peterson C, Nicholls DG, Gibson GE (1985) Subsynaptosomal calcium distribution during aging and 3,4-diaminopyridine treatment. Neurobiol Aging 6, 297304.

[186] Michaelis ML, Bigelow DJ, Schöneich C, Williams TD, Ramonda L, Yin D, Hühmer AF, Yao Y, Gao J, Squier TC (1996) Decreased plasma membrane calcium transport activity in aging brain. Life Sci 59, 405-412.

[187] Martinez A, Vitorica J, Bogonez E, Satrustegui J (1987) Differential effects of age on the pathways of calcium influx into nerve terminals. J Brain Res 435, 249-257.

[188] Berrocal M, Marcos D, Sepulveda MR, Perez M, Avila J, Mata AM (2009) Altered $\mathrm{Ca}^{2+}$ dependence of synaptosomal plasma membrane $\mathrm{Ca}^{2+}$-ATPase in human brain affected by Alzheimer's disease. FASEB J 23, 1826-1834.

[189] Jencks WP, Yang T, Peisach D, Myung J (1993) Calcium ATPase of sarcoplasmic reticulum has four binding sites for calcium. Biochemistry 32, 7030-7034.

[190] Zafar TA (1999) Effect of aluminum on intestinal calbindinD9K in rats. Agricult 15, 227-230.

[191] Cox KA, Dunn MA (2001) Aluminum toxicity alters the regulation of calbindin-D28k protein and mRNA expression in chick intestine. J Nutr 131, 2007-2013.

[192] Orihuelo D, Meichtry V, Pizarro M (2005) Aluminiuminduced impairment of transcellular calcium absorption in the small intestine: Calcium uptake and glutathione influence. J Inorg Biochem 99, 1879-1886.

[193] Kodavanti PRS, Mundy WR, Tilson HA, Harry GJ (1993) Effects of selected neuroactive chemicals on calcium transporting systems in rat cerebellum and on survival of cerebellar granule cells. Fund Appl Toxicol 21, 308-316.

[194] Gandolfi L, Stella MP, Zambenedetti P, Zatta P (1998) Aluminum alters intracellular calcium homeostasis in vitro. Biochim Biophys Acta 1306, 315-320.

[195] Pentyala S, Ruggeri J, Veerraju A, Yu Z, Bhatia A, Desaiah D, Vig P (2001) Microsomal $\mathrm{Ca}^{2+}$ flux modulation as an indicator of heavy metal toxicity. Ind J Exp Biol 48, 737-743.

[196] Mundy WR, Kodavanti PR, Dulchinos VF, Tilson HA (1994) Aluminum alters calcium transport in plasma membrane and endoplasmic reticulum from rat brain. $J$ Biochem Toxicol 9, 17-23.

[197] Fernandes D, Zaidi A, Bean J, Hui D, Michaelis ML (2007) $\mathrm{RNA}_{\mathrm{i}}$-induced silencing of the plasma membrane $\mathrm{Ca}^{2+}$. ATPase 2 in neuronal cells: Effects on $\mathrm{Ca}^{2+}$ homeostasis and cell viability. $J$ Neurochem 102, 454-465.

[198] Deleers M (1985) Cationic atmosphere and cation competition binding at negatively charged membranes: Pathological implications of aluminum. Res Comm Chem Pathol Pharmacol 49, 277-294.

[199] Green KN, Demuro A, Akbari Y, Hitt BD, Smith IF, Parker I, LaFerla FM (2008) SERCA pump activity is physiologically regulated by presenilin and regulates amyloid $\beta$ production. J Cell Biol 181, 1107-1116.

[200] Nelson O, Tu H, Lie T, Mostafa B, de Strooper B, Bezprozvanny I (2007) Familial Alzheimer disease-linked mutations specifically disrupt $\mathrm{Ca}^{+}$leak function of presenilin. J Clin Invest 117, 1230-1239.

[201] Sato N, Hori O, Yamaguchi A, Lambert J-C, Chartier-Harlin M-C, Robinson PA, Delacourte A, Schmidt AM, Furuyama T, Imaizumi K, Tohyama M, Takagi T (1999) A novel presenilin-2 splice variant in human Alzheimer's disease brain tissue. J Neurochem 72, 2498-2505.

[202] Sato N, Imaizumi K, Manabe T, Taniguchi M, Hitomi J, Katayama T, Yoneda T, Morihara T, Yasuda Y, Takagi T, Kudo T, Tsuda T, Itoyama Y, Makifuchi T, Fraser PE, St George-Hyslop P, Tohyama M (2001) Increased production of $\beta$-amyloid and vulnerability to endoplasmic reticulum stress by an aberrant spliced form of presenilin 2. J Biol Chem 276, 2108-2113.

[203] Matsuzaki S, Manabe T, Katayama T, Nishikawa A, Yanagita T, Okuda H, Yasuda Y, Miyata S, Meshitsuka S, Tohyama M (2004) Metals accelerate production of the aberrant splicing isoform of the presenilin-2. J Neurochem $\mathbf{8 8}$, 1345-1351.

[204] Ghribi O, Herman MM, DeWitt DA, Forbes MS, Savory J (2001) Abeta(1-42) and aluminum induce stress in the endoplasmic reticulum in rabbit hippocampus, involving nuclear translocation of gadd 153 and NF-kappaB. Brain Res Mol Brain Res 96, 30-38.

[205] Savory J, Herman MM, Ghribi O (2003) Intracellular mechanisms underlying aluminium-induced apoptosis in rabbit brain. J Inorg Biochem 97, 151-154.

[206] Walton JR (2010) Evidence for participation of aluminum in neurofibrillary tangle formation and growth in Alzheimer's disease. J Alzheimers Dis 22, 65-72.

[207] Hempen B, Brion J-P (1996) Reduction of acetylated $\alpha$ tubulin immunoreactivities in neurofibrillary tangle-bearing neurons in Alzheimer's disease. J Neuropathol Exp Neurol 55, 964-972.

[208] Walton JR (2007) A longitudinal study of rats chronically exposed to aluminum at human dietary levels. Neurosci Lett 412, 29-33.

[209] Flood DG (1993) Critical issues in the analysis of dendritic extent in aging humans, primates, and rodents. Neurobiol Aging 14, 649-634. 